\title{
Chemical Characteristics and Quality Assessment of Groundwater of Exploited Aquifers in Beijiao Water Source of Yinchuan, China: A Case Study for Drinking, Irrigation, and Industrial Purposes
}

\author{
Hao Wu, ${ }^{1,2}$ Jie Chen, ${ }^{1,2}$ Hui Qian,, ${ }^{1,2}$ and Xuedi Zhang ${ }^{1,2}$ \\ ${ }^{1}$ School of Environmental Science and Engineering, Chang'an University, Xian, Shaanxi 710054, China \\ ${ }^{2}$ Key Laboratory of Subsurface Hydrology and Ecological Effect in Arid Region of Ministry of Education, Xian, Shaanxi 710054, China
}

Correspondence should be addressed to Hao Wu; wuhaocc@msn.com

Received 14 February 2015; Accepted 28 May 2015

Academic Editor: Samuel B. Dampare

Copyright (C) 2015 Hao Wu et al. This is an open access article distributed under the Creative Commons Attribution License, which permits unrestricted use, distribution, and reproduction in any medium, provided the original work is properly cited.

\begin{abstract}
This work is aimed at reviewing the chemical characteristics and evaluation of the quality of exploited groundwater in Beijiao water source of Yinchuan. A coupled model based on osculating value method (OVM) and entropy is proposed to determine the suitability for drinking. Besides, phreatic water and confined water are evaluated for irrigation purposes and industrial purposes, respectively. Piper diagram shows different hydrochemical characteristics between aquifers, which can be explained by the control mechanisms revealed by Gibbs diagram. Chloroalkaline indices and ions relationship indicate that reverse ion exchanges occur in different aquifers. Based on the osculating values, $96 \%$ of the phreatic water samples are fit for human consumption, and the confined water can provide quality drinking water. Most of the phreatic water samples have no sodium hazard but have magnesium hazard. All the confined water samples generate mild foaming reaction, and $93 \%$ of them are mildly corrosive for boilers. An assessment by OVM without entropy is calculated. Similar results to the coupled model demonstrate that pure OVM is also objective and valid. The simple algorithm turns multicriteria decision-making problems into an integrated index which is just as useful to water quality assessment.
\end{abstract}

\section{Introduction}

Groundwater is a vital resource, especially in arid and semiarid areas. Sufficient groundwater with high quality is required to meet increasing domestic, agricultural, and industrial needs. Groundwater withdrawals exceeding naturally renewable storage bring about environmental problems, such as forming a cone of depression and extracting nonrenewable groundwater $[1,2]$. The global groundwater crisis is exacerbated by water quality degradation which is closely related to human health [3]. Groundwater quality is determined not only by natural processes such as quality of recharge waters, groundwater velocity, aquifer lithology, and interaction with other types of aquifers, but also by anthropogenic activities such as industry, agriculture, pollution discharge, and water exploitation modifying the hydrological cycle $[4,5]$. The increases of nitrate and sulfate in groundwater in agricultural region are largely attributed to leaching of chemical fertilizer. The irrational irrigation and development of intensive agriculture have resulted in salinization and alkalization of groundwater [6]. Industrial processes create a large amount of effluents and waste residues which are more likely to contain toxic substances. Without proper disposal, the contaminants may infiltrate into aquifers and generate severe pollution. Quantities of domestic waste dumps as well as inadequate discharge and disposal facilities have a significant impact on groundwater quality [7]. 
The rapid development of urbanization has been accompanied by enhanced public awareness and concern regarding protection of groundwater $[8,9]$. Once groundwater is polluted, it is tough restoring its quality with respect to a long time of storage recovery cycle. Therefore, it is critical to monitor and assess the groundwater quality regularly. Numerous researchers across the world explored methods to reflect water quality status. The commonly used methods are Water Quality Index (WQI), improved WQIs (EWQI, FWQI) [10, 11], WQIs by institutions (OWQI, CWQI, CCME WQI, AWQI, and MWQI) $[12,13]$, fuzzy comprehensive assessment method [14], multivariate statistical method [15], matter element extension [16], and neural network [17]. In this study, the osculating value method is introduced for evaluating water quality for drinking purposes. The arithmetic with brief steps is simple and easy to calculate. It does not only classify water quality, but also gives the ranks. Integrated with Shannon entropy as weights, the results are more objective and reasonable.

The study area consists of urban (1/3) in the south and rural $(2 / 3)$ in the center and north (Figure 1). Groundwater from 3 aquifers is being used for various purposes. The upper layer, phreatic water, as the only source of water supply in the rural area is exploited extensively by private individuals. Except for domestic demand, the phreatic water is used for irrigation as water supply source for farming during nonirrigation period and for vegetables in villagers' gardens all year round. The middle and lower layers, confined water, are exploited for municipal water supply network as domestic or industrial consumption. However, the water in the study area is faced with many threats. (1) As an agricultural region, the area has been irrigated using the water from Yellow River for over 2,000 years with a complicated canal system. Besides agricultural pollution, long-term flood irrigation leads to shallow buried depth of groundwater which is adverse to contamination prevention and induces salinization [18]. (2) The water supply wells (confined water) are located in bare sandy land; nowadays, the zone becomes a new urban district due to the rapid urbanization. The groundwater source protection zone was redesigned to the north so as to develop the city, yet the supply wells are not moved. As a result, the protection zone cannot play any role. The fast-growing population has a significant impact on quantity and quality of groundwater. (3) Over exploitation has led to cone of depression in the confined aquifer. The depression cone reduced hydraulic head of the confined aquifer, which causes the phreatic water to recharge confined water. Consequently, the environmentally sensitive phreatic water threatens the confined water quality.

The aims of this study were to understand the groundwater hydrochemistry, detect its control mechanisms, and evaluate the groundwater comprehensively. According to the usage of water, both kinds of groundwater were assessed for drinking purposes by osculating value method integrated with Shannon entropy as weights. In addition, the phreatic water was assessed for irrigation purposes regarding sodium hazard, residual sodium carbonate, and magnesium hazard, whereas the confined water was assessed for industrial use in consideration of effects of incrustation, foaming and corrosion. Before assessment, hydrochemical composition and its controlling factors were explored to get a better understanding of groundwater chemistry.

\section{Study Area}

The study region extends between latitude $38^{\circ} 28^{\prime}-38^{\circ} 40^{\prime} \mathrm{N}$ and longitude $106^{\circ} 02^{\prime}-106^{\circ} 16^{\prime} \mathrm{E}$ with altitude between 1105 and $1125 \mathrm{~m}$ above mean sea level. It covers an area of $242.6 \mathrm{~km}^{2}$ and is located in the northern suburb of Yinchuan city, Ningxia Hui Autonomous Region, northwestern China (Figure 1 ). The city is characterized by a temperate continental arid and semiarid climate with annual average precipitation of $186.94 \mathrm{~mm}$. About $45 \%$ of the precipitation occurs in July and August. The monthly average temperature ranges from $-7.1^{\circ} \mathrm{C}$ in January to $24^{\circ} \mathrm{C}$ in July, with the annual mean value of $9.81^{\circ} \mathrm{C}$. The evaporation is intensive, with a range from 1194.0 to $1743.2 \mathrm{~mm} / \mathrm{a}$ and an average value of $1586.3 \mathrm{~mm} / \mathrm{a}$.

The study region is a part of Yinchuan Plain which is bordered by Helan Mountains on the west and the Yellow River in the east. The landform in the study area consists mainly of proluvial clinoplain, proluvial-alluvial plain, and alluvial-lacustrine plain that distribute zonally from west to east. Small-scale aeolian dunes were deposited in the northeast and west. The Quaternary sediments are thick due to long-term settlement of the rift basin. Within a depth of $250 \mathrm{~m}$, the aquifers are divided into phreatic aquifer, upperconfined aquifer, and lower confined aquifer from the surface down [19]. The aquitard composed of clayey sand and sandy clay between phreatic aquifer and upper-confined aquifer is continuous with a thickness of 10-20 m, while the aquitard between two layers of confined aquifers is not continuous with great variation in thickness, even no more than $1 \mathrm{~m}$ in some area [20]. As a consequence, there exists close hydraulic connection between the confined aquifers.

\section{Materials and Methods}

3.1. Sampling and Analysis. A total of 37 groundwater samples were collected during September 2013. Among them, 23 samples were phreatic groundwater collected from hand-pressed wells or pump wells in different villages, and the remaining 14 samples were collected from 7 pairs of water supply wells in the confined aquifers (Figure 1). The samples were stored in plastic bottles and brown glass. Before sampling, containers were rinsed with groundwater to be taken. After sampling, one plastic bottle was acidified with $\mathrm{HNO}_{3}$, and all containers were sealed immediately. The sample in brown glass for determining the organic compounds was filled without air to avoid oxidation. Before loading, the sampled containers were labeled and packed into incubators. Samples were delivered to the laboratory of Ningxia Environmental Monitoring Center on the same day.

A bulk chemical analysis was carried out for 65 parameters, including $\mathrm{PH}$, total dissolved solid (TDS) as $\mathrm{CaCO}_{3}$, total alkalinity (TA) as $\mathrm{CaCO}_{3}$, total hardness (TH), major 


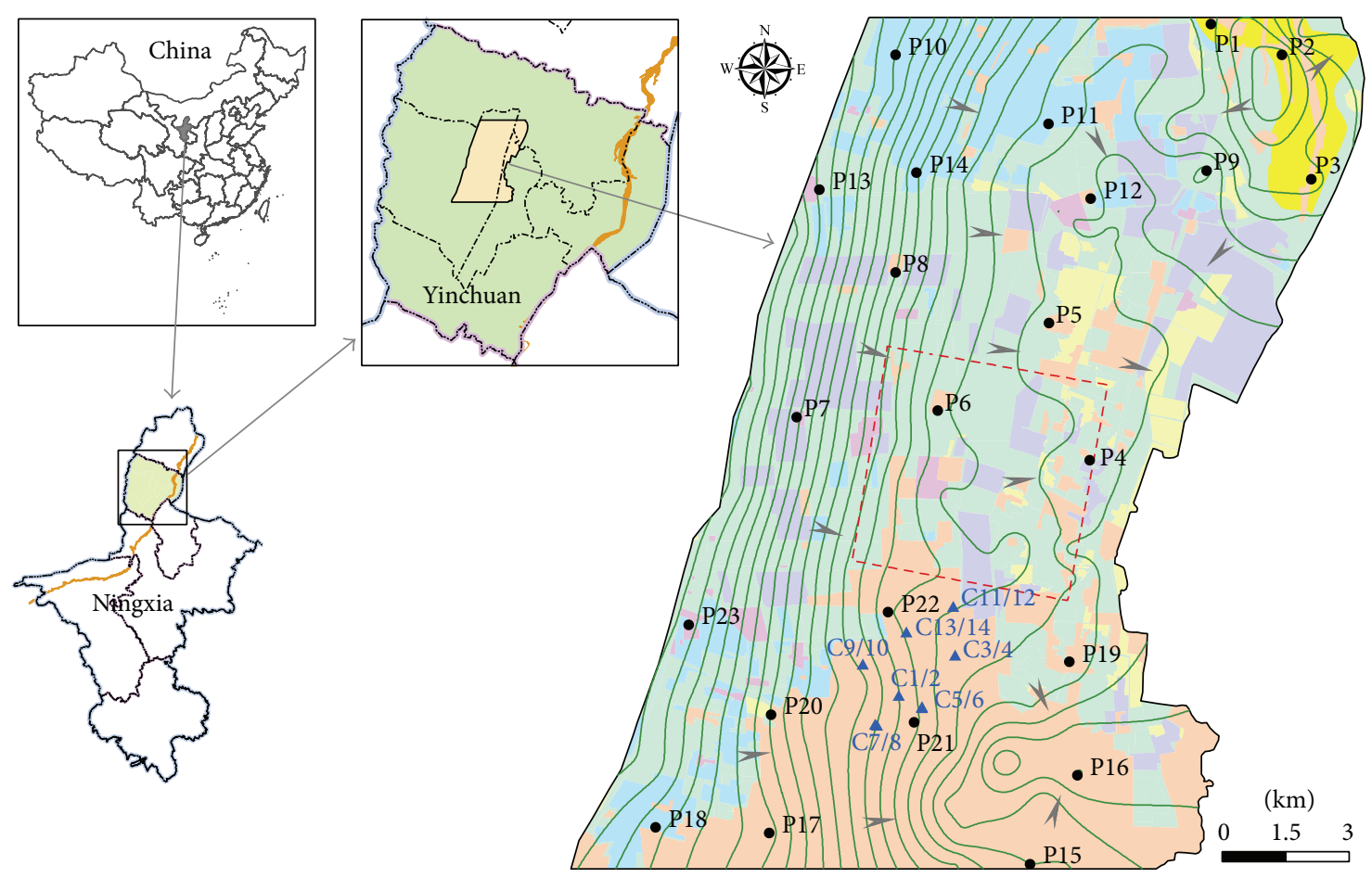

- Phreatic water sampling location

- Confined water sampling location

$>$ Direction of phreatic water flow

- Yellow River

- - Boundary of the water source protection areas

- Phreatic water level contour
Habitation

Aeolian dunes

Industry

Orchard

Cultivated land

Paddy field

Fishpond or wetland

Figure 1: Location map of the study area showing the phreatic water level contour (interval of $1 \mathrm{~m}$ ) and flow direction, land-use type, and sampling locations.

ions $\left(\mathrm{K}^{+}, \mathrm{Na}^{+}, \mathrm{Ca}^{2+}, \mathrm{Mg}^{2+}, \mathrm{Cl}^{-}\right.$, and $\left.\mathrm{SO}_{4}{ }^{2-}\right)$, nitrogen $\left(\mathrm{NH}_{4}{ }^{+}-\right.$ $\mathrm{N}, \mathrm{NO}_{3}{ }^{-}-\mathrm{N}$, and $\left.\mathrm{NO}_{2}{ }^{-}-\mathrm{N}\right)$, fluoride $\left(\mathrm{F}^{-}\right)$, total phosphorus (TP), total cyanide, sulfide, selenium, arsenic, total coliforms (TC), total bacterial count (TBC), metal ions $\left(\mathrm{Hg}, \mathrm{Cr}^{6+}\right.$, $\mathrm{Cr}, \mathrm{Cd}, \mathrm{Cu}, \mathrm{Fe}, \mathrm{Mn}, \mathrm{Ni}, \mathrm{Pb}, \mathrm{V}, \mathrm{Zn}$, and $\mathrm{Al}$ ), organic matters (phenol, volatile phenol, naphthalene, hexachlorocyclohexane $(\mathrm{HCH})$, dichlorodiphenyl trichloroethane (DDT), carbon tetrachloride $\left(\mathrm{CCl}_{4}\right)$, olefins, alkanes, and benzene hydrocarbon).

3.2. Osculating Value Method. The osculating value method is applied to solve multicriteria decision-making problems in system engineering. It has been used in scheme optimization, benefit evaluation, environmental assessment, and many other fields. The steps of osculating value method can be expressed as follows [21-24].

Step 1 (construction of the initial decision matrix). It is assumed that $n$ indices of $m$ samples are taken into evaluation.
An initial decision matrix $\mathbf{C}$ is constructed based on chemical analysis data:

$$
\mathbf{C}=\left[\begin{array}{cccc}
c_{11} & c_{12} & \cdots & c_{1 n} \\
c_{21} & c_{22} & \cdots & c_{2 n} \\
\vdots & \vdots & \ddots & \vdots \\
c_{(m+p) 1} & c_{(m+p) 2} & \cdots & c_{(m+p) n}
\end{array}\right]
$$

where $c_{i j}$ is the concentration of $j$ th index of $i$ th sample $(i=$ $1,2, \ldots, m$, and $j=1,2, \ldots, n)$ and $p$ is the number of rank in criterion. For $i>m, c_{i j}$ is the concentration of each rank.

Step 2 (normalization of the matrix). Generally, multiple indices with different units and ranges are involved in calculation. The relationships among indices are complicated. Some indices are efficiency type (the higher the value, the better the performance), and some are cost type (the higher the value, the worse the performance). Therefore, the initial matrix is 
standardized to get rid of discrepancies. The standardization treatment is expressed as follows:

$$
r_{i j}= \begin{cases}\frac{c_{i j}}{\left[\sum_{i=1}^{m} c_{i j}^{2}\right]^{1 / 2}} & \text { efficiency type } \\ -\frac{c_{i j}}{\left[\sum_{i=1}^{m} c_{i j}^{2}\right]^{1 / 2}} & \text { cost type. }\end{cases}
$$

Standardized decision matrix is written as $\mathbf{R}=\left(r_{i j}\right)_{(m+p) \times n}$.

Step 3 (determination of the optimum and inferior point sets). Let

$$
\begin{aligned}
& r_{j}^{+}=\max \left(r_{1 j}, r_{2 j}, \ldots, r_{(m+p) j}\right), \\
& r_{j}^{-}=\min \left(r_{1 j}, r_{2 j}, \ldots, r_{(m+p) j}\right) .
\end{aligned}
$$

Then, the optimum point set is

$$
\mathbf{G}=\left(r_{1}^{+}, r_{2}^{+}, \ldots, r_{(m+p)}^{+}\right)
$$

And the inferior point set is

$$
\mathbf{B}=\left(r_{1}^{-}, r_{2}^{-}, \ldots, r_{(m+p)}^{-}\right) .
$$

Step 4 (calculation of osculating value). The osculating value $E_{i}$ can be calculated as follows:

$$
E_{i}=\frac{d_{i}^{+}}{\min \left(d_{i}^{+}\right)}-\frac{d_{i}^{-}}{\max \left(d_{i}^{-}\right)},
$$

where

$$
\begin{aligned}
& d_{i}^{+}=\sqrt{\sum_{j=1}^{n} \omega_{j}\left(r_{i j}-r_{j}^{+}\right)^{2}}, \\
& d_{i}^{-}=\sqrt{\sum_{j=1}^{n} \omega_{j}\left(r_{i j}-r_{j}^{-}\right)^{2}} .
\end{aligned}
$$

$\omega_{j}$ is the entropy weight of $j$ th index, $d_{i}^{+}$and $d_{i}^{-}$are the Euclidean distances to the optimum and inferior points, respectively. The values of $E_{i}$ reflect the approach degree of sample points from extreme points. The smaller the value is, the sample point is further to optimum point and closer to inferior point, the better the groundwater quality is.

The method turns multiple indices into an integrated index. The groundwater quality can be obtained by the order of osculating value. The involvement of standard values in initial decision matrix helps to classify groundwater quality into different levels.

3.3. Entropy Theory. Entropy theory was developed by Shannon in 1948 [25]. Shannon entropy, as a measure of information, including disorder, dispersion, and diversification, can reduce the uncertainty of indices by predicting the output of a probabilistic event [26]. It is considered to be an objective method to determine weights. The algorithm has been used in wide scientific fields, including hydrological and environmental sciences [27]. WQIs, TOPSIS, and many other water quality assessment methods were improved by integrating the entropy $[28,29]$. The entropy weight can be calculated as follows $[10,26,28]$.

Step 1 (construction of the initial matrix). Different from initial decision matrix of OVM, the initial matrix $\mathbf{C}^{\prime}$ of entropy weight does not involve concentrations in criterion:

$$
\mathbf{C}^{\prime}=\left[\begin{array}{cccc}
c_{11} & c_{12} & \cdots & c_{1 n} \\
c_{21} & c_{22} & \cdots & c_{2 n} \\
\vdots & \vdots & \ddots & \vdots \\
c_{m 1} & c_{m 2} & \cdots & c_{m n}
\end{array}\right]
$$

where $c_{i j}$ is the concentration of $j$ th index of $i$ th sample.

Step 2 (normalization of the matrix). The initial matrix is normalized by

$$
y_{i j}=\left\{\begin{array}{lc}
\frac{c_{i j}-\left(c_{i j}\right)_{\min }}{\left(c_{i j}\right)_{\max }-\left(c_{i j}\right)_{\min }} & \text { efficiency type, } \\
\frac{\left(c_{i j}\right)_{\max }-c_{i j}}{\left(c_{i j}\right)_{\max }-\left(c_{i j}\right)_{\min }} & \text { cost type. }
\end{array}\right.
$$

Standardized matrix is written as $\mathbf{Y}=\left(y_{i j}\right)_{m \times n}$.

Step 3 (calculation of information entropy). Let

$$
\begin{aligned}
& P_{i j}=\frac{\left(y_{i j}+10^{-4}\right)}{\sum_{i=1}^{m}\left(y_{i j}+10^{-4}\right)}, \\
& e_{j}=-\frac{1}{\ln m} \sum_{i=1}^{m} P_{i j} \ln P_{i j},
\end{aligned}
$$

where $e_{j}$ is the information entropy of $j$ th index, $10^{-4}$ is a refined parameter to ensure the formula meaningful when $y_{i j}$ is 0 .

Step 4 (calculation of entropy weight). Let

$$
\omega_{j}=\frac{1-e_{j}}{\sum_{j=1}^{n}\left(1-e_{j}\right)},
$$

where $\omega_{j}$ is the entropy weight of $j$ th index.

\section{Results and Discussion}

4.1. Statistical Analysis. Statistical analysis of some parameters was carried out to describe the general physiochemical characteristics preliminarily, and the results are presented in Table 1. In order to find out whether it is suitable for drinking, the maximum values were compared with the acceptable limits which are the standards for drinking in Quality 
TABLE 1: Statistics of groundwater quality parameters.

\begin{tabular}{|c|c|c|c|c|c|c|c|c|}
\hline Parameter & Aquifer & Unit & Min & Max & Median & Mean & $\mathrm{CV}$ & Acceptable limits \\
\hline \multirow{2}{*}{$\mathrm{pH}$} & Unconfined & - & 7.27 & 8.08 & 7.87 & 7.78 & 0.03 & \multirow{2}{*}{$6.5-8.5$} \\
\hline & Confined & - & 7.89 & 8.24 & 8.21 & 8.15 & 0.01 & \\
\hline \multirow{2}{*}{ TDS } & Unconfined & $\mathrm{mg} / \mathrm{L}$ & 255 & 1980 & 740 & 864.91 & 0.47 & \multirow{2}{*}{1000} \\
\hline & Confined & $\mathrm{mg} / \mathrm{L}$ & 224 & 267 & 246 & 246.57 & 0.05 & \\
\hline \multirow{2}{*}{$\mathrm{NH}_{4}{ }^{+}-\mathrm{N}$} & Unconfined & $\mathrm{mg} / \mathrm{L}$ & 0.046 & 0.34 & 0.06 & 0.08 & 0.75 & \multirow{2}{*}{0.2} \\
\hline & Confined & $\mathrm{mg} / \mathrm{L}$ & 0.116 & 0.362 & 0.21 & 0.22 & 0.31 & \\
\hline \multirow{2}{*}{ TA } & Unconfined & $\mathrm{mg} / \mathrm{L}$ & 149 & 701 & 336 & 334.78 & 0.36 & \multirow{2}{*}{-} \\
\hline & Confined & $\mathrm{mg} / \mathrm{L}$ & 188 & 251 & 203.5 & 206.29 & 0.08 & \\
\hline \multirow{2}{*}{$\mathrm{TH}$} & Unconfined & $\mathrm{mg} / \mathrm{L}$ & 210 & 1089 & 531 & 512.35 & 0.39 & \multirow{2}{*}{450} \\
\hline & Confined & $\mathrm{mg} / \mathrm{L}$ & 179 & 222 & 194 & 197.50 & 0.07 & \\
\hline \multirow{2}{*}{$\mathrm{COD}_{\mathrm{Mn}}$} & Unconfined & $\mathrm{mg} / \mathrm{L}$ & ND & 2.1 & 1 & 1.03 & 0.44 & \multirow{2}{*}{3} \\
\hline & Confined & $\mathrm{mg} / \mathrm{L}$ & ND & 1 & 0.65 & 0.67 & 0.25 & \\
\hline \multirow{2}{*}{$\mathrm{NO}_{2}{ }^{-}-\mathrm{N}$} & Unconfined & $\mathrm{mg} / \mathrm{L}$ & ND & 0.211 & ND & - & - & \multirow{2}{*}{0.02} \\
\hline & Confined & $\mathrm{mg} / \mathrm{L}$ & ND & ND & ND & ND & 0 & \\
\hline \multirow{2}{*}{$\mathrm{Na}^{+}$} & Unconfined & $\mathrm{mg} / \mathrm{L}$ & 42.6 & 371 & 157 & 178.8 & 0.47 & \multirow{2}{*}{200} \\
\hline & Confined & $\mathrm{mg} / \mathrm{L}$ & 26.7 & 61.5 & 32.4 & 34.37 & 0.26 & \\
\hline \multirow{2}{*}{$\mathrm{K}^{+}$} & Unconfined & $\mathrm{mg} / \mathrm{L}$ & 4.29 & 42.1 & 7.01 & 10.24 & 0.84 & \multirow{2}{*}{-} \\
\hline & Confined & $\mathrm{mg} / \mathrm{L}$ & 3.13 & 8.94 & 5.48 & 5.73 & 0.38 & \\
\hline \multirow{2}{*}{$\mathrm{Mg}^{2+}$} & Unconfined & $\mathrm{mg} / \mathrm{L}$ & 27.2 & 213 & 71.8 & 79.54 & 0.52 & \multirow{2}{*}{150} \\
\hline & Confined & $\mathrm{mg} / \mathrm{L}$ & 24.2 & 29.5 & 26.2 & 26.47 & 0.06 & \\
\hline \multirow{2}{*}{$\mathrm{Ca}^{2+}$} & Unconfined & $\mathrm{mg} / \mathrm{L}$ & 39.9 & 163 & 87.8 & 88.03 & 0.35 & \multirow{2}{*}{200} \\
\hline & Confined & $\mathrm{mg} / \mathrm{L}$ & 32.7 & 69.3 & 38.5 & 41.89 & 0.21 & \\
\hline $\mathrm{F}^{-}$ & Unconfined & $\mathrm{mg} / \mathrm{L}$ & 0.14 & 1.82 & 0.38 & 0.57 & 0.84 & 1 \\
\hline & Confined & $\mathrm{mg} / \mathrm{L}$ & 0.27 & 0.43 & 0.34 & 0.34 & 0.14 & 1 \\
\hline $\mathrm{Cl}^{-}$ & Unconfined & $\mathrm{mg} / \mathrm{L}$ & 62.5 & 335 & 147 & 177.35 & 0.45 & 250 \\
\hline & Confined & $\mathrm{mg} / \mathrm{L}$ & 55.5 & 75.7 & 64.85 & 64.48 & 0.09 & 250 \\
\hline $\mathrm{NO}^{-}-\mathrm{N}$ & Unconfined & $\mathrm{mg} / \mathrm{L}$ & 1.99 & 26.2 & 6.53 & 8.51 & 0.94 & 20 \\
\hline $\mathrm{NO}_{3}-\mathrm{N}$ & Confined & $\mathrm{mg} / \mathrm{L}$ & 0.87 & 2.63 & 1.22 & 1.45 & 0.40 & \\
\hline $\operatorname{so}^{2+}$ & Unconfined & $\mathrm{mg} / \mathrm{L}$ & 47.6 & 466 & 279 & 264.45 & 0.49 & 250 \\
\hline$U_{4}$ & Confined & $\mathrm{mg} / \mathrm{L}$ & 30.5 & 47.8 & 36.5 & 37.64 & 0.13 & 250 \\
\hline $\mathrm{Fe}$ & Unconfined & $\mathrm{mg} / \mathrm{L}$ & ND & 0.101 & 0.003 & $<0.012$ & - & $\ldots$ \\
\hline 10 & Confined & $\mathrm{mg} / \mathrm{L}$ & 0.078 & 0.25 & 0.183 & 0.15 & 0.33 & \\
\hline $\mathrm{Mn}$ & Unconfined & $\mathrm{mg} / \mathrm{L}$ & ND & 0.737 & 0.002 & $<0.050$ & - & - \\
\hline & Confined & $\mathrm{mg} / \mathrm{L}$ & 0.036 & 0.077 & 0.065 & 0.06 & 0.17 & \\
\hline $\mathrm{So}_{0}$ & Unconfined & $\mathrm{mg} / \mathrm{L}$ & $\mathrm{ND}$ & $1.76 \times 10^{-3}$ & $2.43 \times 10^{-4}$ & - & - & 0.01 \\
\hline Se & Confined & $\mathrm{mg} / \mathrm{L}$ & ND & $6.00 \times 10^{-3}$ & ND & - & - & 0.01 \\
\hline $\mathrm{Hg}$ & Unconfined & $\mathrm{mg} / \mathrm{L}$ & $1.60 \times 10^{-5}$ & $1.85 \times 10^{-4}$ & $3.70 \times 10^{-5}$ & $6.38 \times 10^{-5}$ & 0.77 & 0001 \\
\hline & Confined & $\mathrm{mg} / \mathrm{L}$ & $2.50 \times 10^{-5}$ & $1.84 \times 10^{-4}$ & $9.30 \times 10^{-5}$ & $9.64 \times 10^{-5}$ & 0.51 & 0.001 \\
\hline As & Unconfined & $\mathrm{mg} / \mathrm{L}$ & $1.74 \times 10^{-4}$ & $1.35 \times 10^{-3}$ & $5.63 \times 10^{-4}$ & $5.99 \times 10^{-4}$ & 0.45 & 0.05 \\
\hline & Confined & $\mathrm{mg} / \mathrm{L}$ & $1.51 \times 10^{-4}$ & $1.28 \times 10^{-3}$ & $2.83 \times 10^{-4}$ & $3.89 \times 10^{-4}$ & 0.77 & \\
\hline TC & Unconfined & $\mathrm{mpn} / \mathrm{L}$ & ND & 2005 & 222 & - & - & 3 \\
\hline & Confined & $\mathrm{mpn} / \mathrm{L}$ & ND & 150 & ND & - & - & \\
\hline TBC & Unconfined & $\mathrm{cfu} / \mathrm{mL}$ & 0 & 102 & 20 & 30.8 & 1.1 & 100 \\
\hline $10 \mathrm{C}$ & Confined & $\mathrm{cfu} / \mathrm{mL}$ & 0 & 12 & 0 & 1.14 & 2.82 & 100 \\
\hline
\end{tabular}

$\mathrm{CV}$ : coefficient of variation; ND: not detected.

Standard for Ground Water (QSGW) of China. For $\mathrm{Na}^{+}$, $\mathrm{Mg}^{2+}$, and $\mathrm{Ca}^{2+}$, which are not included in QSGW, Guidelines for Drinking-water Quality by Word Health Organization (WHO) are used instead.
Among the 22 parameters considered of the phreatic samples, the maximum of 12 parameters consisting of TDS, $\mathrm{TH}, \mathrm{Na}^{+}, \mathrm{Mg}^{2+}, \mathrm{NH}_{4}{ }^{+}-\mathrm{N}, \mathrm{NO}_{3}{ }^{-}-\mathrm{N}, \mathrm{NO}_{2}{ }^{-}-\mathrm{N}, \mathrm{Cl}^{-}, \mathrm{SO}_{4}{ }^{2+}, \mathrm{F}^{-}$, $\mathrm{TC}$, and TBC are beyond the acceptable limits. Fortunately, 
the average concentrations of 8 parameters including TDS, $\mathrm{Na}^{+}, \mathrm{Mg}^{2+}, \mathrm{NH}_{4}^{+}-\mathrm{N}, \mathrm{NO}_{3}{ }^{-}-\mathrm{N}, \mathrm{NO}_{2}{ }^{-}-\mathrm{N}, \mathrm{Cl}^{-}$, and $\mathrm{F}^{-}$do not exceed the acceptable limits. The average concentrations of $\mathrm{TH}, \mathrm{NO}_{2}{ }^{-}-\mathrm{N}$, and $\mathrm{SO}_{4}{ }^{2+}$ are $512 \mathrm{mg} / \mathrm{L}, 0.023 \mathrm{mg} / \mathrm{L}$, and $264 \mathrm{mg} / \mathrm{L}$ that are higher than acceptable limits $450 \mathrm{mg} / \mathrm{L}$, $0.02 \mathrm{mg} / \mathrm{L}$, and $250 \mathrm{mg} / \mathrm{L}$, respectively. Whereas, the concentrations of $\mathrm{NO}_{2}{ }^{-}-\mathrm{N}$ in 14 samples are below the detection limits of $0.003 \mathrm{mg} / \mathrm{L}$, and the median of ND implied that only a few samples are polluted but severely.

The concentrations of parameters of the confined samples are lower than those of the phreatic samples obviously except $\mathrm{NH}_{4}{ }^{+}-\mathrm{N}, \mathrm{Fe}, \mathrm{Mn}$, and $\mathrm{Hg}$. Still, $\mathrm{NH}_{4}{ }^{+}-\mathrm{N}$, and TC of some confined samples exceed the acceptable limits. And 10 of the 14 samples (71\%) have exceeded $\mathrm{NH}_{4}{ }^{+}-\mathrm{N}$. Ji [30] investigated the reasons for the high concentration of $\mathrm{NH}_{4}{ }^{+}-\mathrm{N}$ of the confined groundwater in Yinchuan. The source of $\mathrm{NH}_{4}{ }^{+}$ comes from chemical fertilizer, and anoxic condition caused by flood irrigation goes against nitrification which transforms $\mathrm{NH}_{4}{ }^{+}$to $\mathrm{NO}_{3}{ }^{-}$. The $\mathrm{NH}_{4}{ }^{+}$infiltrates into the confined aquifers by leakage recharge and encouraged by increased water head difference caused by overexploited confined water. It has been suggested that approximately $70 \%$ of recharge of upper-confined water comes from the phreatic aquifer [31]. The high Fe and Mn contents in the confined water, in general caused by geological environment [32], are another reason to be responsible for $\mathrm{NH}_{4}{ }^{+}$pollution. As reducing agents, $\mathrm{Fe}$ and $\mathrm{Mn}$ are involved into redox reactions with oxidant $\mathrm{NO}_{3}{ }^{-}$ in neutral or weak alkaline environment. The reactions are expressed as

$$
\begin{aligned}
2 \mathrm{Fe}(\mathrm{OH})_{2}+\mathrm{NO}_{3}{ }^{-}+\mathrm{H}_{2} \mathrm{O} & \rightleftharpoons \mathrm{NO}_{2}{ }^{-}+2 \mathrm{Fe}(\mathrm{OH})_{3} \\
\mathrm{Mn}(\mathrm{OH})_{2}+\mathrm{NO}_{3}{ }^{-} & \rightleftharpoons \mathrm{MnO}_{2}+\mathrm{NO}_{2}{ }^{-}+\mathrm{H}_{2} \mathrm{O}
\end{aligned}
$$

The reactions reduce $\mathrm{NO}_{3}{ }^{-}$and produce $\mathrm{NO}_{2}{ }^{-}$which is unstable. In the reaction processes, iron bacteria oxidize ferrous iron to ferric iron by using molecular oxygen and synthesize organic compounds using energy from the reactions, which consumes oxygen further [33]. The hypoxic environment inhibits nitrification, which accumulates $\mathrm{NH}_{4}{ }^{+}$. Ji [30] verified that there exist negative correlation between $\mathrm{NO}_{3}{ }^{-}$and $\mathrm{Fe} / \mathrm{Mn}$, nonlinear relationship between $\mathrm{NO}_{2}{ }^{-}$and $\mathrm{Fe} / \mathrm{Mn}$ due to instability of $\mathrm{NO}_{2}{ }^{-}$, and positive correlation between $\mathrm{NH}_{4}{ }^{+}$and Fe/Mn. Similar relationships were found in groundwater in Shunyi District, Beijing [34].

4.2. Groundwater Types. For the phreatic water samples, the cationic strength was observed as $\mathrm{Na}^{+}>\mathrm{Mg}^{2+}>\mathrm{Ca}^{2+}>$ $\mathrm{K}^{+}$with percentages of $40.22 \%, 33.88 \%, 24.23 \%$, and $1.66 \%$, respectively. The percentages of $\mathrm{HCO}_{3}{ }^{-}>\mathrm{SO}_{4}{ }^{2-}>\mathrm{Cl}^{-}$ are $40.40 \%, 30.58 \%$, and $29.02 \%$, respectively. The dominant elements of the confined water are quite different from that of the phreatic water. Cation dominances of the confined water were observed as $\mathrm{Mg}^{2+}>\mathrm{Ca}^{2+}>\mathrm{Na}^{+}>\mathrm{K}^{+}$, and their percentages are $37.27 \%, 35.21 \%, 25.07 \%$, and $2.45 \%$, respectively. The percentages of $\mathrm{HCO}_{3}{ }^{-}>\mathrm{Cl}^{-}>\mathrm{SO}_{4}{ }^{2-}$ were observed as $61.57 \%, 26.88 \%$, and $11.55 \%$, respectively. The main cations are $\mathrm{Na}^{+}, \mathrm{Mg}^{2+}$, and $\mathrm{Ca}^{2+}$ in the phreatic water and confined water, respectively, and main anions are $\mathrm{HCO}_{3}{ }^{-}$in both types of water.

Piper trilinear diagram, which was conceived by Hill [35] and improved by Piper [36], is a widely used tool to understand the hydrochemical regime and facies classification of groundwater and surface water [37, 38]. Sample points with similar hydrochemistry tend to cluster together in the diagram. Hydrochemical facies were distinguished by equal $50 \%$ increments which are more helpful than equal 25\% increments [39]. As shown in Figure 2, there are no dominant cations and anions for most phreatic water samples, except 6 samples that are dominated by $\mathrm{Na}^{+}$and discrepant 6 samples dominated by $\mathrm{HCO}_{3}{ }^{-}$. For samples from the confined aquifers, the anion chemistry is controlled by $\mathrm{HCO}_{3}{ }^{-}$, and the cation chemistry has no dominant ions. Except sample P10 identified as $\mathrm{Na}-\mathrm{HCO}_{3}$ type, all the other phreatic samples were classified into mixed type due to no cation-anion exceeding 50\%. The diamond-shaped field showed that alkaline earths exceed alkalis and strong acids exceed weak acids for all confined water.

There is a huge difference in point distribution between the phreatic water and confined water in the diagram. The former has dispersed distribution, while the latter has concentrated distribution. This indicates that more complicated controlling factors exist in shallow groundwater than deep groundwater. The composition of elements implies weathering of carbonate minerals is the primary controlling factor. However, hydrochemistry of shallow groundwater is affected by evaporation considerably, because relative to the confined water, the phreatic water tends to have a higher proportion of $\mathrm{Na}^{+}+\mathrm{K}^{+}$and $\mathrm{SO}_{4}{ }^{2-}$, a lower proportion of $\mathrm{Ca}^{2+}$ and $\mathrm{HCO}_{3}{ }^{-}+\mathrm{CO}_{3}{ }^{2-}$ which are shown in the triangular field. This behavior is the consequence of $\mathrm{CaCO}_{3}$ precipitation under evaporation that results in the phreatic water becomes alkaline. The similar hydrochemical proportions of samples from two layers of confined aquifers confirm the close hydraulic connection between them.

4.3. Ion Exchange. Water chemical composition changes during its travel or residence in the subsurface [40]. Aquifer materials are the sources of dissolved ions and encourage cation exchange and reverse ion exchange. In particular, for montmorillonite, it releases $\mathrm{Na}^{+}$or $\mathrm{Ca}^{2+}$ into groundwater to exchange $\mathrm{Ca}^{2+}$ or $\mathrm{Na}^{+}$[41]. In aquifer composed of unconsolidated deposits, a mass of clay minerals exist and adsorb cations in their pore space [42]. To get insight into the base exchange reaction between groundwater and its host environment, Schoeller [43] suggested two chloroalkaline indices CAI-I and CAI-II:

$$
\begin{aligned}
\text { CAI-I } & =\frac{\mathrm{Cl}^{-}-\left(\mathrm{Na}^{+}+\mathrm{K}^{+}\right)}{\mathrm{Cl}^{-}} \\
\text {CAI-II } & =\frac{\mathrm{Cl}^{-}-\left(\mathrm{Na}^{+}+\mathrm{K}^{+}\right)}{\mathrm{SO}_{4}{ }^{2-}+\mathrm{HCO}_{3}{ }^{-}+\mathrm{CO}_{3}{ }^{2-}+\mathrm{NO}_{3}{ }^{-}} .
\end{aligned}
$$

If $\mathrm{Ca}^{2+}$ or $\mathrm{Mg}^{2+}$ in groundwater is exchanged with $\mathrm{Na}^{+}$ or $\mathrm{K}^{+}$in the host rocks, both of the two indices are negative, whereas a reverse ion exchange gives positive indices $[44,45]$. 


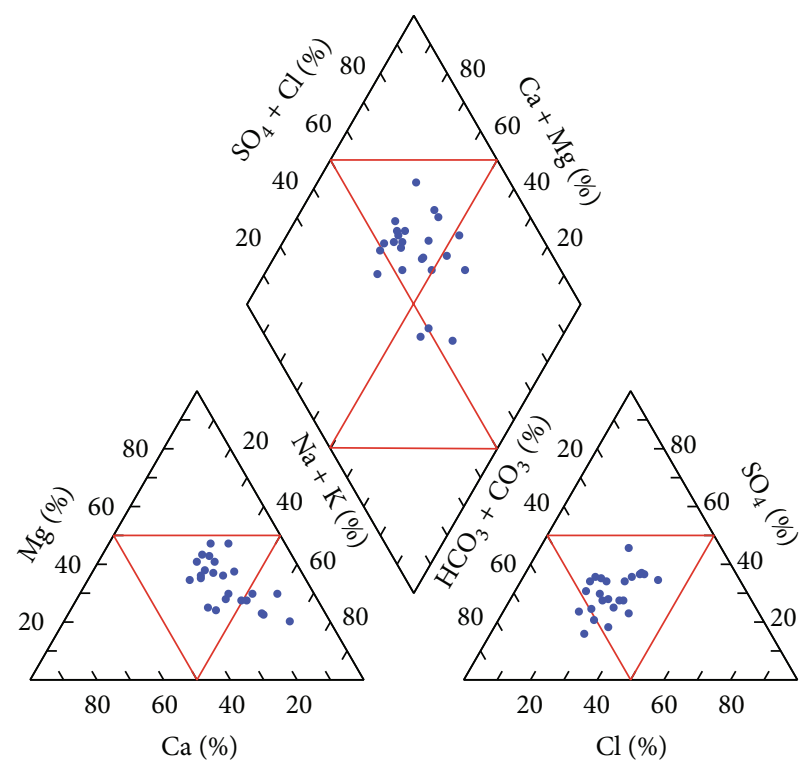

- Phreatic water

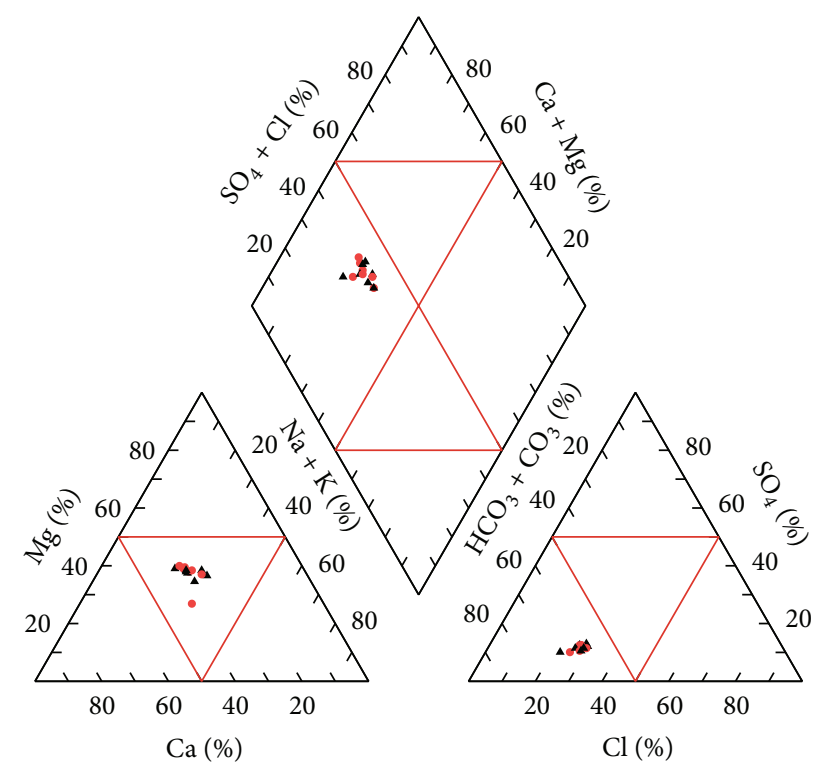

- Lower confined water

- Upper-confined water

(a)

(b)

FIGURE 2: The piper diagrams for the phreatic water samples (a) and the confined water samples (b).

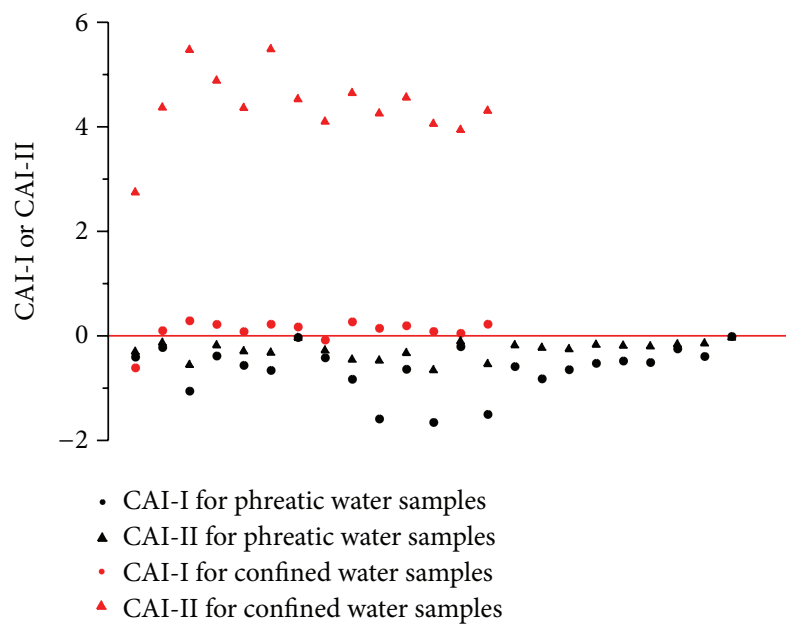

FIGURE 3: Chloroalkaline indices (CAI-I and CAI-II) for the phreatic water samples and the confined water samples.

Figure 3 showed both indices are negative for all the phreatic water samples and positive for most confined water samples except for CAI-I of samples $\mathrm{C} 1$ and C8. The opposite signs for the phreatic and confined water indicate contrary ion exchange processes take place in the two types of water. This potentially explains the relative abundance of $\mathrm{Na}^{+}$in the phreatic water and the abundance of alkaline earth, especially $\mathrm{Mg}^{2+}$, in the confined water.

In the water environment dominated by the dissolutions of calcite, dolomite, and gypsum, the relationship between $\left(\mathrm{Ca}^{2+}+\mathrm{Mg}^{2+}\right)$ and $\left(\mathrm{SO}_{4}{ }^{2-}+\mathrm{HCO}_{3}{ }^{-}\right)$is close to $1: 1[46,47]$.

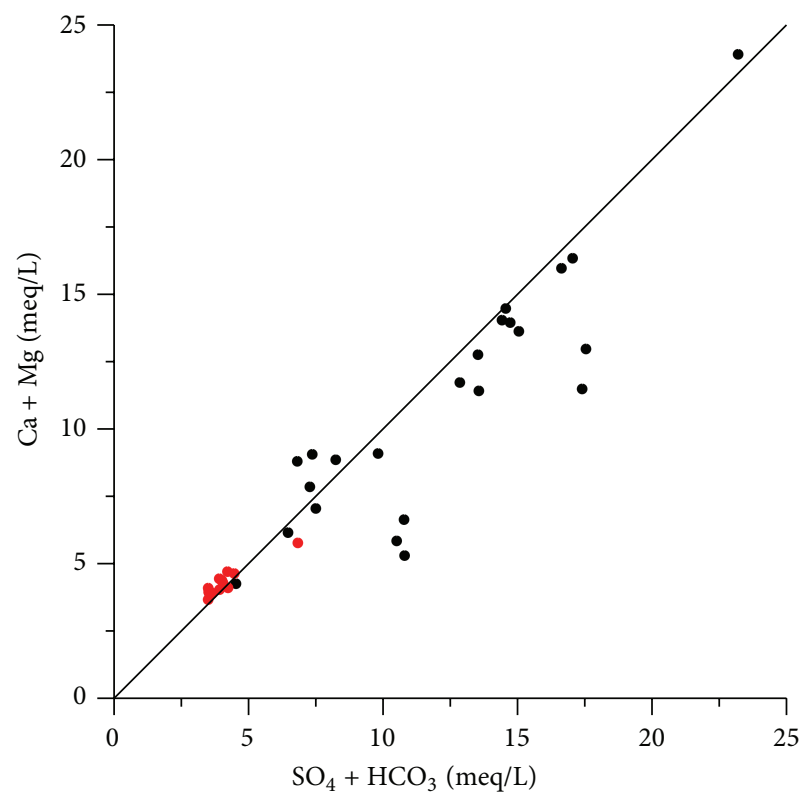

- Phreatic water

- Confined water

FIgURE 4: Scatter plot for $\mathrm{SO}_{4}+\mathrm{HCO}_{3}$ versus $\mathrm{Ca}+\mathrm{Mg}$.

The ion exchange known as direct tends to shift the points because of the excess of $\left(\mathrm{SO}_{4}{ }^{2-}+\mathrm{HCO}_{3}{ }^{-}\right)$over $\left(\mathrm{Ca}^{2+}+\right.$ $\left.\mathrm{Mg}^{2+}\right)$. Whereas the reverse ion exchange shifts the points to the left due to increased $\mathrm{Ca}^{2+}$ and/or $\mathrm{Mg}^{2+}$ released by rocks $[47,48]$. Figure 4 showed $78 \%$ of the phreatic water samples are below the $1: 1$ line due to a deficiency of $\mathrm{Ca}^{2+}$ and $\mathrm{Mg}^{2+}$. As 


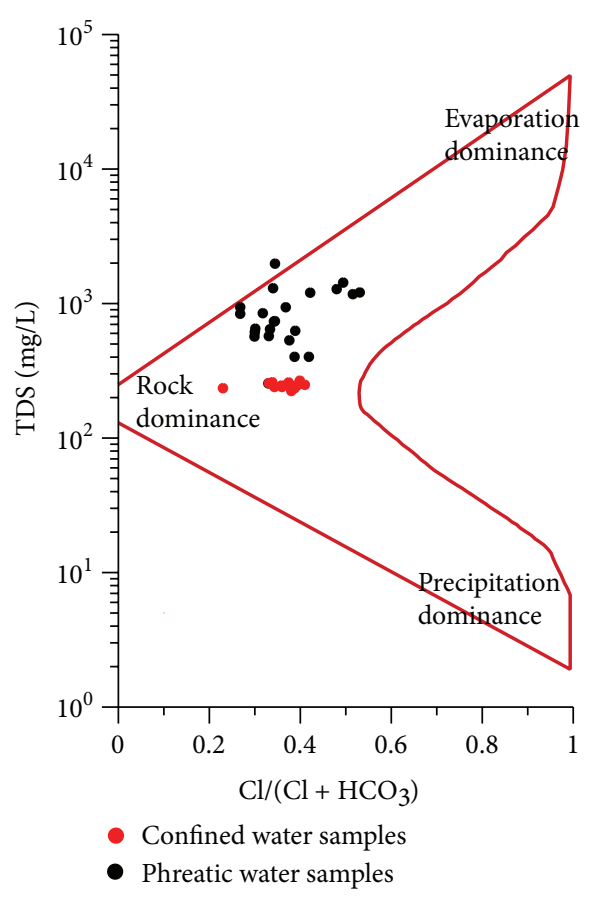

(a)

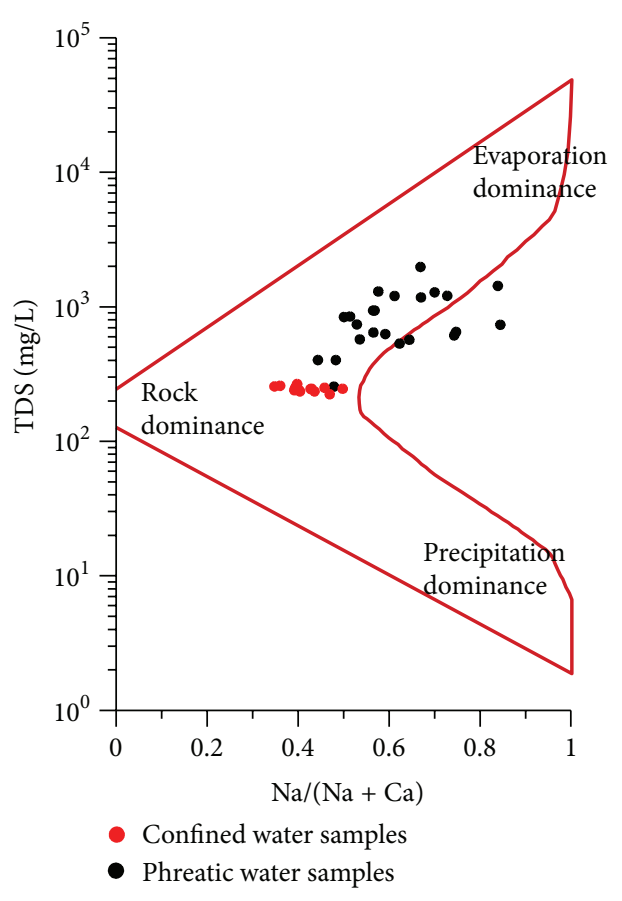

(b)

FIgURE 5: Gibbs diagram showing TDS versus (a) $\mathrm{Cl} /\left(\mathrm{Cl}+\mathrm{HCO}_{3}\right)$ and (b) $\mathrm{Na} /(\mathrm{Na}+\mathrm{Ca})$.

a result, $\mathrm{Na}^{+}$must balance the excessive anions. The abundant $\mathrm{Na}^{+}$is evidence of the ion exchange process. And $86 \%$ of the confined water samples fall above the $1: 1$ line which indicates the reverse ion exchange dominancy.

Gibbs diagram is used to detect mechanisms that control the hydrochemical components in surface water [49] and groundwater $[47,50]$. The values of TDS are plotted against ratios of dominant cations $[\mathrm{Na} /(\mathrm{Na}+\mathrm{Ca})]$ or anions $[\mathrm{Cl} /(\mathrm{Cl}$ $\left.+\mathrm{HCO}_{3}\right)$ ] [51]. The diagram is divided into three zones representing different controlling mechanisms which are evaporation, rock, and precipitation (rainfall) dominance from top to bottom. The chemical analyses of phreatic and confined water samples were plotted in the Gibbs diagram (Figure 5). It showed all the confined water samples fall in the rock dominance zone entirely which is compatible with storage conditions. Whereas, the phreatic water samples falling in the zone between evaporation and rock dominance demonstrate a mixed controlling mechanism. Evaporation results in increased TDS relative to the confined water with relation to high ratios of dominant cations and anions, especially sodium ions, due to $\mathrm{CaCO}_{3}$ precipitate caused by the combination of $\mathrm{Ca}^{2+}$ and $\mathrm{HCO}_{3}{ }^{-}$. Huge quantities of irrigation return flow elevated groundwater level, hence increases evaporation and induce salinization.

4.4. Water Quality for Drinking Purposes. Quality Standard for Ground Water (QSGW) of China was chosen as evaluation criterion. The core indices (TDS, TH, $\mathrm{COD}_{\mathrm{Mn}}, \mathrm{NH}_{4}{ }^{+}-$ $\mathrm{N}, \mathrm{NO}_{3}{ }^{-}-\mathrm{N}, \mathrm{NO}_{2}{ }^{-}-\mathrm{N}, \mathrm{Cl}^{-}, \mathrm{SO}_{4}{ }^{2+}$, and $\mathrm{F}^{-}$) and some other indices ( $\mathrm{Se}, \mathrm{Hg}, \mathrm{As}, \mathrm{TC}$, and $\mathrm{TBC}$ ) included in QSGW were opted for assessment. A separate calculation of osculating value based on entropy was processed for the phreatic groundwater and confined groundwater, on account of disparities in physiochemical characteristic, source, and storage condition. The results are present in Tables 2 and 3. Four groups of criteria (S1, S2, S3, and S4) in QSGW classified groundwater quality into five ranks.

Ranking of the phreatic water samples (Table 2) showed that 4 samples are excellent quality water (rank 1), 1 sample belongs to good quality water (rank 2), 17 samples are classified in medium quality category (rank 3 ), and 1 sample is poor quality water (rank 4). Groundwater in ranks 1, 2, and 3 is suitable for drinking according to QSGW of China. Except for sample P4 with osculating value of 5.29 that is just greater than the standard value of rank 3 of 5.13, all the other phreatic samples are appropriate for human consumption.

Ranking of the confined water samples (Table 3 ) revealed that 12 samples had the good quality (rank 2) and 2 samples had the medium quality (rank 3 ). This indicates that mixing water from supply wells can provide quality drinking water.

The majority of the phreatic samples $(73.9 \%)$ belong to rank 3, while most confined samples (85.7\%) are rank 2. A level worse than the confined water to the phreatic water is consistent with their characteristics. The results suggest that the phreatic water has been adversely affected by human activities, such as increased nitrogen caused by infiltration of fertilizers and pesticides in the Yellow River irrigated agricultural region, and high numbers of coliforms and bacterial counts due to backwardness of toilet, waste disposal, and other sanitation in the rural area. In spite of 
TABLE 2: Assessment results of osculating values method with entropy and without entropy for the phreatic water samples.

\begin{tabular}{|c|c|c|c|c|}
\hline \multirow{2}{*}{ Sample number } & \multicolumn{2}{|c|}{ OVM with entropy } & \multicolumn{2}{|c|}{ OVM without entropy } \\
\hline & Osculating value & Rank & Osculating value & Rank \\
\hline $\mathrm{P} 1$ & 2.43 & 3 & 2.17 & 3 \\
\hline P2 & 0.29 & 1 & 0.48 & 1 \\
\hline P3 & 0.4 & 1 & 0.58 & 1 \\
\hline P4 & 5.29 & 4 & 4.95 & 3 \\
\hline P5 & 0 & 1 & 0 & 1 \\
\hline P6 & 1.61 & 3 & 1.64 & 3 \\
\hline P7 & 1.56 & 3 & 1.6 & 3 \\
\hline P8 & 0.35 & 1 & 0.48 & 1 \\
\hline P9 & 3.67 & 3 & 3.7 & 3 \\
\hline P10 & 1.42 & 3 & 1.45 & 3 \\
\hline P11 & 2.34 & 3 & 2.16 & 3 \\
\hline $\mathrm{P} 12$ & 0.72 & 2 & 0.94 & 2 \\
\hline $\mathrm{P} 13$ & 1.69 & 3 & 0.99 & 2 \\
\hline P14 & 1.11 & 3 & 2.19 & 3 \\
\hline P15 & 3.76 & 3 & 3.19 & 3 \\
\hline P16 & 4.35 & 3 & 4.2 & 3 \\
\hline P17 & 2.78 & 3 & 2.62 & 3 \\
\hline P18 & 1.07 & 3 & 1.02 & 2 \\
\hline P19 & 3.83 & 3 & 3.13 & 3 \\
\hline P20 & 3.09 & 3 & 2.23 & 3 \\
\hline P21 & 2.42 & 3 & 2.33 & 3 \\
\hline P22 & 1.43 & 3 & 1.44 & 3 \\
\hline P23 & 2.27 & 3 & 1.5 & 3 \\
\hline S1 & 0.47 & & 0.73 & \\
\hline S2 & 1.05 & & 1.26 & \\
\hline S3 & 5.13 & & 5.99 & \\
\hline S4 & 13.18 & & 16.06 & \\
\hline
\end{tabular}

drinkable of the phreatic water, it is urgent to concern and improve the groundwater quality because osculating values of some phreatic samples are close to the critical value of drinkable.

Contour map of osculating value with entropy for the phreatic water was interpolated by kriging with Gaussian variogram model (Figure 6). The osculating value contour map showed inconsistency with the phreatic water level contour in the west, even opposition in some regions. The rank 4 region is downstream of the phreatic water, and it is the center of a small town with a population of high density but poor sanitation. The northeast corner (rank 1) of the study area is small-scale aeolian dunes where land is wasteland or poor farmland. These are also evidence that anthropogenic activities are responsible for groundwater pollution.

The results assessed by osculating value without entropy were also listed in Tables 2 and 3 for comparison. The comparison reveals that entropy has a minor influence on the ranks. Only 3 phreatic samples and 1 confined sample have different ranks. And the different ranks just have one level change. This demonstrates pure osculating value method is objective which is a great advantage of the algorithm. The
TABLE 3: Assessment results of osculating values method with entropy and without entropy for the confined water samples.

\begin{tabular}{lcccc}
\hline \multirow{2}{*}{ Sample number } & \multicolumn{2}{c}{ OVM with entropy } & \multicolumn{2}{c}{ OVM without entropy } \\
Osculating value & Rank & Osculating value & Rank \\
\hline C1 & 0.23 & 2 & 0.01 & 1 \\
C2 & 2.49 & 3 & 2.16 & 3 \\
C3 & 1.03 & 2 & 0.74 & 2 \\
C4 & 1.22 & 2 & 0.93 & 2 \\
C5 & 4.11 & 3 & 4.54 & 3 \\
C6 & 0.61 & 2 & 0.31 & 2 \\
C7 & 0.77 & 2 & 0.48 & 2 \\
C8 & 2.00 & 2 & 1.66 & 2 \\
C9 & 0.88 & 2 & 0.67 & 2 \\
C10 & 0.26 & 2 & 0.13 & 2 \\
C11 & 1.43 & 2 & 1.14 & 2 \\
C12 & 1.13 & 2 & 0.86 & 2 \\
C13 & 1.63 & 2 & 1.35 & 2 \\
C14 & 1.06 & 2 & 0.79 & 2 \\
S1 & 0.02 & & 0.06 & \\
S2 & 2.39 & & 1.82 & \\
S3 & 9.07 & & 7.04 & \\
S4 & 17.55 & & 16.97 & \\
\hline
\end{tabular}

pure osculating value method is also reasonable and useful. The method is applicable to other countries and criteria by exchanging QSGW of China in the initial decision matrix for other standard values. An assessment without standard values is also feasible; thus, a score and rank can be obtained for each sample.

\subsection{Water Quality for Irrigation Purposes}

4.5.1. Sodium Hazard. Sodium is the mainly concerned parameter when assessing the suitability of groundwater for irrigation. Groundwater with high concentration of sodium ions is undesirable to irrigate crops. In Na-enriched groundwater, $\mathrm{Mg}^{2+}$ and $\mathrm{Ca}^{2+}$ will be released from soil into groundwater, while $\mathrm{Na}^{+}$will be adsorbed onto the soil resulting from the cation exchange processes. On the contrary, $\mathrm{Na}^{+}$will be released from cation exchange sites and $\mathrm{Ca}^{2+}$ ions are adsorbed in groundwater that is rich in $\mathrm{Ca}^{2+}$ [52]. Overburdened sodium ions in the soil affect the behavior of the colloidal fraction and lead to soil aggregates to disperse that result in decrease of soil permeability, and hardening of the soil affects plough and seedling emergence [53-55]. In addition, saline and alkaline soils, which are harmful to plant growth, are formed by combining sodium with chloride and carbonate, respectively [41].

Sodium adsorption ratio (SAR), used by the United States Salinity Laboratory, was used as the primary indicator for evaluating irrigation $[56,57]$. The sodium percentage $(\mathrm{Na} \%)$ expressed as a ratio of $\mathrm{Na}^{+}$and $\mathrm{K}^{+}$concentration to $\mathrm{Na}^{+}$, 


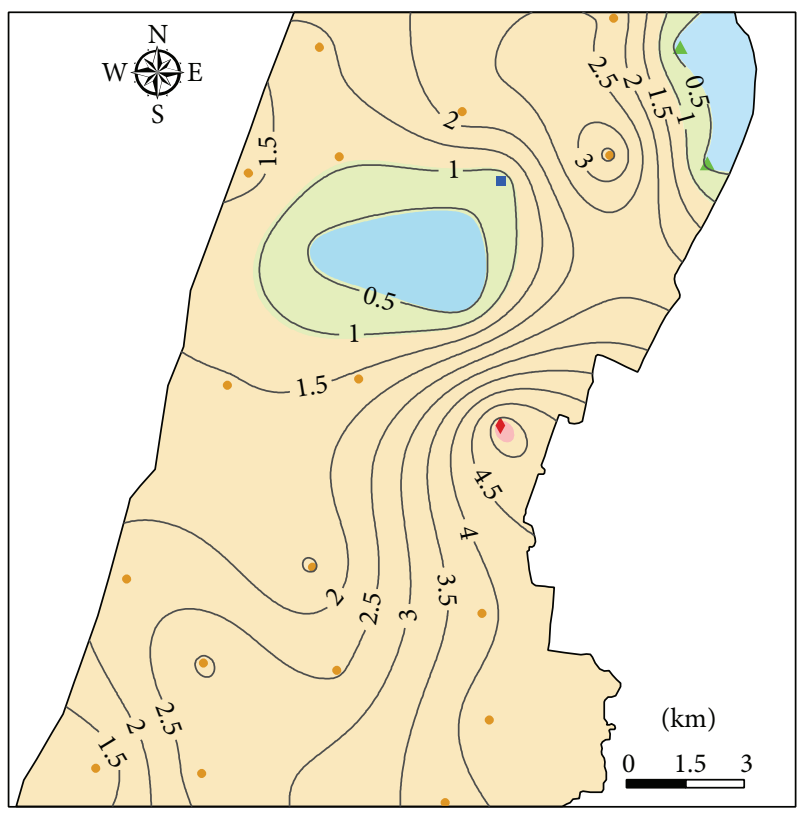

Rank of samples

- Rank 1

- $\operatorname{Rank} 2$

- Rank 3

- Rank 4

Phreatic water quality by OVM

Rank 1

Rank 2

Rank 3

Rank 4

FIgURE 6: Contour map of osculating value and classification of the phreatic water quality by OVM with entropy.

$\mathrm{K}^{+}, \mathrm{Ca}^{2+}$, and $\mathrm{Mg}^{2+}$ concentration is another indicator used widely [58]:

$$
\begin{aligned}
\mathrm{SAR} & =\frac{\mathrm{Na}^{+}}{\sqrt{\left(\mathrm{Ca}^{2+}+\mathrm{Mg}^{2+}\right) / 2}} \\
\mathrm{Na} \% & =\frac{\mathrm{Na}^{+}+\mathrm{K}^{+}}{\mathrm{Na}^{+}+\mathrm{K}^{+}+\mathrm{Ca}^{2+}+\mathrm{Mg}^{2+}} \times 100,
\end{aligned}
$$

where the concentrations of all ions are in meq/L. Figure 7(a) showed SAR of the phreatic water in the study area fall within the range between 1.27 and 6.73, all much smaller than the safe value 9 with no structural deterioration $[59,60]$. It means that all the water samples meet the general requirements for irrigation. However, the values of $\mathrm{Na} \%$ are in the range of 29.2-67.5, beyond the permissible limits of 60 partially (Figure 7(b)). In fact, $\mathrm{Na} \%$ of sample P12 is 67.5, while the rest of samples within the permissible limits. The results indicated that sample P12 is unsuitable for irrigation because of sodium hazard.

4.5.2. Residual Sodium Carbonate. Generally, water loses after irrigation because of evaporation and evapotranspiration. Hence, the concentration of soil solution is elevated which causes the precipitation of $\mathrm{Ca}^{2+}$ and $\mathrm{Mg}^{2+}$ combined with $\mathrm{CO}_{3}{ }^{2-}$ and $\mathrm{HCO}_{3}{ }^{-}$[61]. Meanwhile, the percentage of $\mathrm{Na}^{+}$arises and high $\mathrm{Na}^{+}$content increases the SAR and exchangeable $\mathrm{Na}^{+}$of soil solution [62]. If the concentration

of carbonates is greater than that of alkaline earths, $\mathrm{NaHCO}_{3}$ which can affect soil structure will be formed by combining $\mathrm{Na}^{+}$with the rest of carbonates after precipitation [63]. Residual sodium carbonate (RSC) expresses as the concentration of carbonates minus the concentration of alkaline earths [41, 64]:

$$
\begin{aligned}
\mathrm{RSC} & =\left(\mathrm{HCO}_{3}{ }^{-}+\mathrm{CO}_{3}{ }^{2-}\right)-\left(\mathrm{Ca}^{2+}+\mathrm{Mg}^{2+}\right) \\
& =\mathrm{TA}-\left(\mathrm{OH}^{-}+\mathrm{Ca}^{2+}+\mathrm{Mg}^{2+}\right),
\end{aligned}
$$

where TA represents the concentration of total alkalinity (as $\mathrm{CaCO}_{3}$ ) and the concentrations of all parameters are expressed in meq/L. The concentration of $\mathrm{OH}^{-}$is less than $10^{-3} \mathrm{meq} / \mathrm{L}$ which can be ignored compared to the values of other parameters, when $\mathrm{PH}$ is within the range of 6 and 8 [64]. Irrigation water was classified based on RSC values of less than $1.25,1.25-2.5$, and greater than 2.5 as suitable, marginal, and unsuitable, respectively [65]. As per the data, the values of RSC range from -9.9 to 1.5 , and 2 samples (P10 and P12) fall into the marginal range, while others fall into the suitable range (Figure $7(\mathrm{c})$ ). This indicates that sodium hazard caused by exceeded carbonates is light.

4.5.3. Magnesium Hazard. A high level of $\mathrm{Mg}^{2+}$ in the soil can be expected to result in alkaline which damages soil structure and affects crop yields. Normally, irrigation water of high concentration of $\mathrm{Mg}^{2+}$ makes soils release $\mathrm{Na}^{+}$and exchange $\mathrm{Mg}^{2+}$ in the water [63]. In the study area, the equilibrium of cation exchange processes is as the above case which is proved by CAI-I and CAI-II. So, magnesium ratio (MR) was carried out to evaluate the magnesium hazard proposed by Szaboles and Darab [66]:

$$
\mathrm{MR}=\frac{\mathrm{Mg}^{2+}}{\mathrm{Ca}^{2+}+\mathrm{Mg}^{2+}} \times 100,
$$

where all ionic concentrations are expressed in meq/L. If $M R$ is more than 50 , the water is considered to be harmful to soil and affects the crop yields. The values of MR in the study area vary from 42.1 to 73.1 . It is found that 21 samples of all the 23 phreatic water samples (91.3\%) exceed the permissible limit of MR (Figure 7(d)). Only sample P6 and P7 have no magnesium hazard with magnesium ratios of 42.1 and 49.6, respectively, which are closed to the limit.

4.6. Water Quality for Industrial Purposes. Water used for industry is one of the important parts of urban water supply. Its requirements of water quality are very different from drinking and irrigation purposes, even altered in various industries [67]. Each industry has its own standards for water. Boiler water is quite common and requires high quality water. Generally, they suffer from three effects of incrustation, foaming and corrosion which are caused by adverse chemical reaction under the condition of high temperature and high pressure $[9,68]$.

4.6.1. Incrustation. Boiler scale attached to the boiler wall is adverse to heat transfer, hence wastes fuel, even melts 


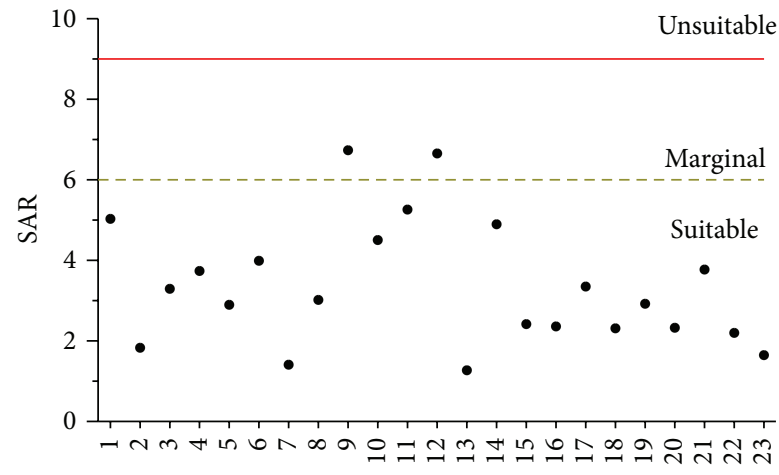

Phreatic water sample number

(a)

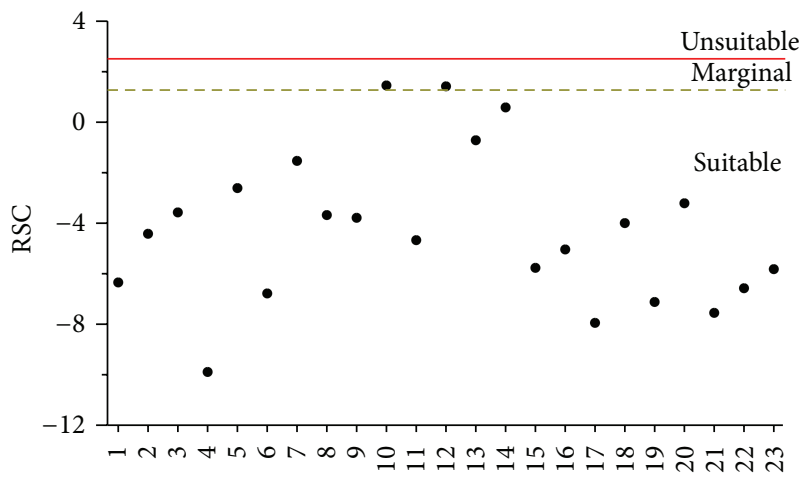

Phreatic water sample number

(c)

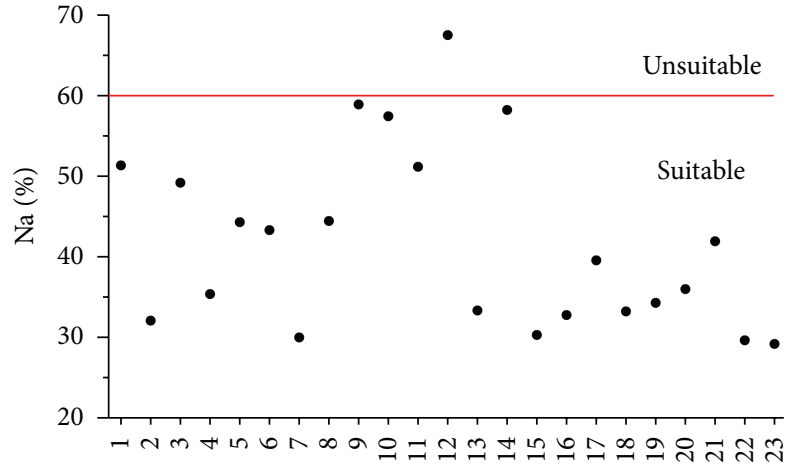

Phreatic water sample number

(b)

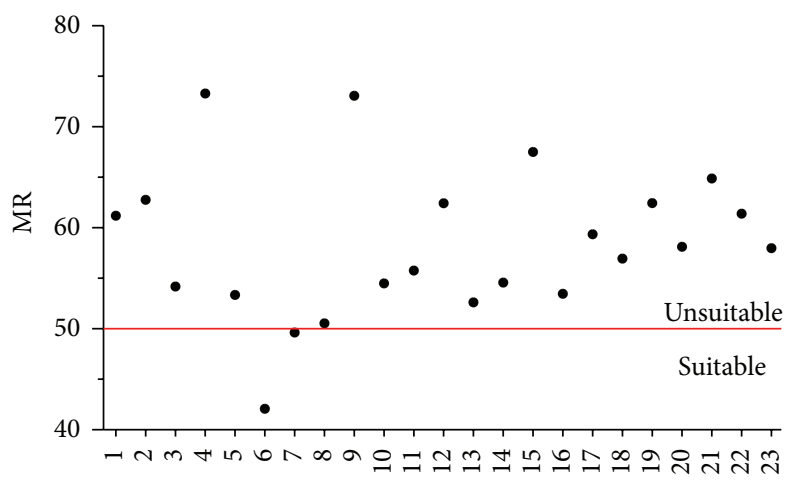

Phreatic water sample number

(d)

Figure 7: (a) SAR, (b) Na\%, (c) RSC, and (d) MR for the phreatic water samples.

boiler or causes an explosion. It is formed by precipitation of calcium salt, magnesium salt, $\mathrm{SiO}_{2}, \mathrm{Al}_{2} \mathrm{O}_{3}, \mathrm{Fe}_{2} \mathrm{O}_{3}$, and suspended solids dissolved in water. When water boils, precipitation reactions take place and form $\mathrm{CaCO}_{3}, \mathrm{Mg}(\mathrm{OH})_{2}$, $\mathrm{CaSO}_{4}, \mathrm{CaSiO}_{3}, \mathrm{MgSiO}_{3}, \mathrm{CaO}$, and so forth which are insoluble compounds. Some common reactions can be expressed as follows [68]:

$$
\begin{aligned}
& \mathrm{Ca}^{2+}+2 \mathrm{HCO}_{3}-\stackrel{\Delta}{\rightarrow} \mathrm{CaCO}_{3} \downarrow+\mathrm{H}_{2} \mathrm{O}+\mathrm{CO}_{2} \uparrow \\
& \mathrm{Mg}^{2+}+2 \mathrm{HCO}_{3}{ }^{-} \stackrel{\Delta}{\rightarrow} \mathrm{MgCO}_{3} \downarrow+\mathrm{H}_{2} \mathrm{O}+\mathrm{CO}_{2} \uparrow \\
& \mathrm{MgCO}_{3}+2 \mathrm{H}_{2} \mathrm{O} \longrightarrow \mathrm{Mg}(\mathrm{OH})_{2} \downarrow+\mathrm{H}_{2} \mathrm{O}+\mathrm{CO}_{2} \uparrow
\end{aligned}
$$

Three parameters can be adopted to decide the properties of incrustation. The concentrations of $\mathrm{TH}, \mathrm{HCO}_{3}{ }^{-}$, and $\mathrm{SO}_{4}{ }^{2-}$ are greater than $300 \mathrm{mg} / \mathrm{L}, 400 \mathrm{mg} / \mathrm{L}$ and $100 \mathrm{mg} / \mathrm{L}$, respectively, may cause incrustation [63]. As per the data of 14 confined groundwater samples, $\mathrm{TH}, \mathrm{HCO}_{3}{ }^{-}$, and $\mathrm{SO}_{4}{ }^{2-}$ are in the range of $179-222 \mathrm{mg} / \mathrm{L}, 167-365 \mathrm{mg} / \mathrm{L}$, and $30.5-$ $47.8 \mathrm{mg} / \mathrm{L}$. All the parameters are within the limits, this showed that no worry about incrustation.

4.6.2. Foaming. Water bubbled up to the surface when boiled. While bubbles cannot break open in time, thick and unstable bubbles are formed. Too many bubbles elevate the water table resulting in boilers not working. This is a result of the saponification reaction related to sodium $(\mathrm{Na})$, potassium $(\mathrm{K})$, grease, and suspended solids [69]. The foaming coefficient is a measure of foaming action:

$$
F=62 \times \mathrm{Na}^{+}+78 \times \mathrm{K}^{+}
$$

where the concentrations of sodium and potassium are expressed in meq/L. The water of no foaming action is $F<60$, and that of foaming action is $F>200$. While $F$ is in the range of 60-200, the water is marginal. As per the data of 14 samples, the values of $F$ range from 78.88 to 182.01 , which all belong to marginal range. It means that locomotive water boiler needs to be refreshed at least two or three days. As for no foaming action water, refreshing once a week is required.

4.6.3. Corrosion. Corrosive actions extremely damage the boiler, notably under high steam pressure. It eats metal through replacement reaction, even bring about explosion accidents. It was reported that 119 boilers exploded caused by corrosion at least once during 1956 and 1970 in 640 investigative boilers in the USA [68]. Corrosive actions are influenced by many factors, such as $\mathrm{H}^{+}, \mathrm{O}_{2}, \mathrm{H}_{2} \mathrm{~S}, \mathrm{CO}_{2}, \mathrm{Fe}_{2} \mathrm{~S}_{3}$, organic matters. The corrosive coefficient is an indicator that reflects the intensity of corrosion. 
For acidic water, the corrosive coefficient is expressed as

$$
\begin{aligned}
K & =1.008\left(\mathrm{H}^{+}+\mathrm{Al}^{3+}+\mathrm{Fe}^{2+}+\mathrm{Mg}^{2+}-\mathrm{CO}_{3}{ }^{2-}\right. \\
& \left.-\mathrm{HCO}_{3}{ }^{-}\right) .
\end{aligned}
$$

For alkaline water, the corrosive coefficient is expressed as

$$
K=1.008\left(\mathrm{Mg}^{2+}-\mathrm{HCO}_{3}^{-}\right) \text {, }
$$

where all ionic concentrations are expressed in meq/L. When $K>0$, the water is corrosive. For $K<0$, if $K+0.0503 \mathrm{Ca}^{2+}<$ 0 , the water is not corrosive; otherwise, the water is mildly corrosive, where $\mathrm{Ca}^{2+}$ is expressed in $\mathrm{mg} / \mathrm{L}$. As per the data, all the confined water samples are alkaline water $(7.89<\mathrm{pH}<$ $8.24)$, and the values of $K$ vary from -3.71 to -0.60 which are all negative. The values of $K+0.0503 \mathrm{Ca}^{2+}$ range from -0.22 to 1.50 . The results show that sample $\mathrm{C} 1$ is not corrosive, while others are mildly corrosive.

\section{Conclusions}

Three aquifers in Yinchuan northern suburb which are exploited and utilized by human were investigated to evaluate the groundwater quality for drinking, irrigation, and industrial purposes.

Statistical analysis showed the quality of the confined water samples is better than the phreatic water samples. Nevertheless, the concentration of $\mathrm{NH}_{4}{ }^{+}-\mathrm{N}$ of the confined water exceeds drinkable limits generally, which is conspicuous and abnormal. This can attribute to multiple reasons, such as fertilizer leakage, flood irrigation, over exploitation, and redox reactions.

The Piper diagram revealed different chemical composition between the phreatic water and confined water, which implied different controlling factors. The phreatic water is mixed type, whereas the confined water has dominant anion of $\mathrm{HCO}_{3}{ }^{-}$and no dominant cations. The triangular field in the diagram implied $\mathrm{CaCO}_{3}$ precipitation caused by evaporation results in alkalization for the phreatic water. The phreatic water has negative values of CAI-I and CAI-II, which has positive values for most confined water. This indicated that $\mathrm{Ca}^{2+}$ or $\mathrm{Mg}^{2+}$ in the phreatic water is exchanged with $\mathrm{Na}^{+}$or $\mathrm{K}^{+}$in the host rocks, and a reverse ion exchange proceeds in the confined water. The relationship between $\left(\mathrm{Ca}^{2+}+\mathrm{Mg}^{2+}\right)$ and $\left(\mathrm{SO}_{4}{ }^{2-}+\mathrm{HCO}_{3}{ }^{-}\right)$verified the different ion exchanges. Gibbs diagrams showed different controlling mechanisms of chemical components apparently. The confined water is entirely rock dominance, including ion exchange and precipitation/dissolution. The phreatic water is controlled by water-rock interaction and evaporation. Due to long-term flood irrigation, the shallow buried depth of groundwater greatly enhanced the evaporation.

The osculating value method with entropy was used to assess groundwater quality for drinking purpose. About $17 \%$, $4 \%, 74 \%$, and $4 \%$ of the phreatic samples have excellent, good, medium, and poor quality, respectively, and about $86 \%$ and $14 \%$ of the confined samples belong to good and medium quality water, respectively. The results stated that all the water samples, except for one phreatic sample, are fit for human consumption, and the confined aquifers can provide quality drinking water. In spite of this, groundwater is polluted by human in terms of high nitrogen content, coliforms and bacterial contamination, and inconsistent osculating value contour. The comparison between OVM with and without entropy showed that OVM without entropy is also objective and valid. Hence, OVM is an excellent algorithm for groundwater quality assessment.

The calculation of SAR, Na\%, RSC, and MR of the phreatic water indicated that most phreatic water has no sodium hazard but has magnesium hazard which can give rise to alkaline and damage soil structure. Thus, the phreatic water is not appropriate for irrigation.

Industrial suitability of the confined water was evaluated in terms of incrustation, foaming, and corrosion. The results showed that all the confined water samples have no incrustation harm to boilers, but they can generate mild foaming reaction, and most of them are mildly corrosive. For the sake of security, boiler water needs to be refreshed every couple of days.

\section{Conflict of Interests}

The authors declare that there is no conflict of interests regarding the publication of this paper.

\section{Acknowledgments}

The research was supported by the National Natural Science Foundation of China (41172212), the Study on Water Environmental Early Warning in Ningxia, and the Doctoral Postgraduate Technical Project of Changan University (2014G5290005). Sincere thanks are due to Dr. Wanfang Zhou, a hydrogeologist/engineering geologist of P.E. LaMoreaux and Associates, Inc. (PELA), for improvement of the paper and valuable comments. Special thanks are given to the anonymous reviewers and editors for their useful comments to improve quality of the study.

\section{References}

[1] Z. Jamshidzadeh and S. A. Mirbagheri, "Evaluation of groundwater quantity and quality in the Kashan Basin, Central Iran," Desalination, vol. 270, no. 1-3, pp. 23-30, 2011.

[2] J. Chen, H. Wu, H. Qian, and Q. Liu, "Analysis of evolvement for confined water cone of depression and its influence on groundwater resource sustainability in Yinchuan area," Advanced Materials Research, vol. 1073-1076, pp. 1656-1659, 2014.

[3] T. N. Narasimhan, "On adapting to global groundwater crisis," Ground Water, vol. 48, no. 3, pp. 354-357, 2010.

[4] B. Helena, R. Pardo, M. Vega, E. Barrado, J. M. Fernandez, and L. Fernandez, "Temporal evolution of groundwater composition in an alluvial aquifer (Pisuerga River, Spain) by principal component analysis," Water Research, vol. 34, no. 3, pp. 807-816, 2000.

[5] Y. J. Jiang, Y. X. Wu, C. Groves, D. X. Yuan, and P. Kambesis, "Natural and anthropogenic factors affecting the groundwater 
quality in the Nandong karst underground river system in Yunan, China," Journal of Contaminant Hydrology, vol. 109, no. 1-4, pp. 49-61, 2009.

[6] Y.-J. Jiang, C. Zhang, D.-X. Yuan, G. Zhang, and R.-S. He, "Impact of land use change on groundwater quality in a typical karst watershed of southwest China: a case study of the Xiaojiang watershed, Yunnan Province," Hydrogeology Journal, vol. 16, no. 4, pp. 727-735, 2008.

[7] B. Abdelkader, M. Abdelhak, K. Abdeslam, M. Ahmed, and Z. Brahim, "Estimation of pollution load of domestic sewage to oued bechar (SWAlgeria) and its impact on the microbiological quality of groundwater," Procedia Engineering, vol. 33, pp. 261$267,2012$.

[8] V. K. Grabert, “The word style 'groundwater' reflects increased public awareness of the resource," Ground Water, vol. 47, no. 4, pp. 470-474, 2009.

[9] S. Varol and A. Davraz, "Evaluation of the groundwater quality with WQI (Water Quality Index) and multivariate analysis: a case study of the Tefenni plain (Burdur/Turkey)," Environmental Earth Sciences, vol. 73, no. 4, pp. 1725-1744, 2014.

[10] L. Pei-Yue, Q. Hui, and W. Jian-Hua, "Groundwater quality assessment based on improved water quality index in Pengyang County, Ningxia, Northwest China," E-Journal of Chemistry, vol. 7, supplement 1, pp. S209-S216, 2010.

[11] A. Lermontov, L. Yokoyama, M. Lermontov, and M. A. S. Machado, "River quality analysis using fuzzy water quality index: Ribeira do Iguape river watershed, Brazil," Ecological Indicators, vol. 9, no. 6, pp. 1188-1197, 2009.

[12] A. Mostafaei, "Application of multivariate statistical methods and water-quality index to evaluation of water quality in the Kashkan River," Environmental Management, vol. 53, no. 4, pp. 865-881, 2014.

[13] A. Lumb, T. C. Sharma, J. F. Bibeault, and P. Klawunn, "A comparative study of usa and canadian water quality index models," Water Quality, Exposure and Health, vol. 3, no. 3-4, pp. 203-216, 2011.

[14] Y. Icaga, "Fuzzy evaluation of water quality classification," Ecological Indicators, vol. 7, no. 3, pp. 710-718, 2007.

[15] S. K. Chapagain, V. P. Pandey, S. Shrestha, T. Nakamura, and F. Kazama, "Assessment of deep groundwater quality in kathmandu valley using multivariate statistical techniques," Water, Air, and Soil Pollution, vol. 210, no. 1-4, pp. 277-288, 2010.

[16] J. Jing, Q. Hui, C. Yu-Fei, and X. Wen-Juan, "Assessment of groundwater quality based on matter element extension model," Journal of Chemistry, vol. 2013, Article ID 715647, 7 pages, 2013.

[17] F. Modaresi and S. Araghinejad, "A comparative assessment of support vector machines, probabilistic neural networks, and k-nearest neighbor algorithms for water quality classification," Water Resources Management, vol. 28, no. 12, pp. 4095-4111, 2014.

[18] H. Wu, J. W. Qi, H. Qian, J. Chen, and X.-D. Zhang, "Groundwater quality affected by yellow river irrigated agriculture in Northern Suburb of Yinchuan, China," Advanced Materials Research, vol. 1073-1076, pp. 1035-1038, 2014.

[19] H. Qian, J. Wu, Y. Zhou, and P. Li, "Stable oxygen and hydrogen isotopes as indicators of lake water recharge and evaporation in the lakes of the Yinchuan Plain," Hydrological Processes, vol. 28, no. 10, pp. 3554-3562, 2014.

[20] H. Wu, Groundwater vulnerability and health risk assessment in Yinchuan Beijiao water resource [M.S. thesis], Chang'an University, Xian, China, 2014, (Chinese).
[21] Z.-X. Jing and R. Hu, "Sensitivity analysis for power quality evaluation and its application in modified close value method," Power System Protection and Control, vol. 41, no. 9, pp. 60-66, 2013.

[22] Y. Sun, K.-L. Hu, Z.-B. Fan, Y.-P. Wei, S. Lin, and J.-G. Wang, "Simulating the fate of nitrogen and optimizing water and nitrogen management of greenhouse tomato in North China using the EU-Rotate_N model," Agricultural Water Management, vol. 128, pp. 72-84, 2013.

[23] G.-D. Chen, "Comprehensive assessment and analysis on the status of heavy metal pollution in soil of Yindongliang lead-zinc mine area in Fengxian," Chinese Journal of Soil Science, vol. 44, pp. 222-226, 2013, (Chinese).

[24] B. Lu, Z. Zhang, M. Zhu, Z. Chen, and X. Lu, "Evaluation for development effect of agricultural mechanization based on method of global osculating value," Transactions of the Chinese Society of Agricultural Machinery, vol. 39, no. 5, pp. 56-59, 2008, (Chinese).

[25] C. E. Shannon, "A mathematical theory of communication," The Bell System Technical Journal, vol. 27, pp. 379-423, 1948.

[26] G. S. Shyu, B. Y. Cheng, C. T. Chiang, P. H. Yao, and T. K. Chang, "Applying factor analysis combined with kriging and information entropy theory for mapping and evaluating the stability of groundwater quality variation in Taiwan," International Journal of Environmental Research and Public Health, vol. 8, no. 4, pp. 1084-1109, 2011.

[27] V. P. Singh, "The use of entropy in hydrology and water resources," Hydrological Processes, vol. 11, no. 6, pp. 587-626, 1997.

[28] L. Liu, J. Zhou, X. An, Y. Zhang, and L. Yang, "Using fuzzy theory and information entropy for water quality assessment in Three Gorges region, China," Expert Systems with Applications, vol. 37, no. 3, pp. 2517-2521, 2010.

[29] D. Wang, V. P. Singh, and Y. S. Zhu, "Hybrid fuzzy and optimal modeling for water quality evaluation," Water Resources Research, vol. 43, no. 5, Article ID W05415, 2007.

[30] Y.-D. Ji, Evaluation of groundwater quality and cause analysis of nitrogen pollution in Yinchuan [M.S. thesis], Chang'an University, Xian, China, 2003, (Chinese).

[31] Z.-H. Zhang, Study on the groundwater pollution simulation in Yinchuan region [M.S. thesis], Chang'an University, Xian, China, 2014, (Chinese).

[32] S. Carretero and E. Kruse, "Iron and manganese content in groundwater on the northeastern coast of the Buenos Aires Province, Argentina," Environmental Earth Sciences, vol. 73, no. 5, pp. 1983-1995, 2015.

[33] W. Yang, Y. Wang, Y. Guo, W. Liu, and S. Lin, “Test about effect of iron and manganese on nitrogen transformation in underground water," Journal of Shenyang Jianzhu University, vol. 24, no. 2, pp. 286-290, 2008, (Chinese).

[34] Y.-T. Li, G.-X. Zhen, D.-W. Chen et al., "The distribution of ammonia nitrogen in groundwater of Shunyi and its influencing factors," Journal of Environment and Health, vol. 24, pp. 706708, 2007, (Chinese).

[35] R. A. Hill, "Geochemical patterns in Coachella Valley," Eos, Transactions American Geophysical Union, vol. 21, no. 1, pp. 4653, 1940.

[36] A. M. Piper, "A graphic procedure in the geochemical interpretation of water-analyses," Eos, Transactions American Geophysical Union, vol. 25, no. 6, pp. 914-928, 1944. 
[37] R. K. Ray and R. Mukherjee, "Reproducing the Piper trilinear diagram in rectangular coordinates," Ground Water, vol. 46, no. 6, pp. 893-896, 2008.

[38] N. Otero, R. Tolosana-Delgado, A. Soler, V. Pawlowsky-Glahn, and A. Canals, "Relative vs. absolute statistical analysis of compositions: a comparative study of surface waters of a Mediterranean river," Water Research, vol. 39, no. 7, pp. 14041414, 2005.

[39] P. Li, J. Wu, and H. Qian, "Assessment of groundwater quality for irrigation purposes and identification of hydrogeochemical evolution mechanisms in Pengyang County, China," Environmental Earth Sciences, vol. 69, no. 7, pp. 2211-2225, 2013.

[40] N. Arveti, M. R. S. Sarma, J. A. Aitkenhead-Peterson, and K. Sunil, "Fluoride incidence in groundwater: a case study from Talupula, Andhra Pradesh, India," Environmental Monitoring and Assessment, vol. 172, no. 1-4, pp. 427-443, 2011.

[41] R. Nagarajan, N. Rajmohan, U. Mahendran, and S. Senthamilkumar, "Evaluation of groundwater quality and its suitability for drinking and agricultural use in Thanjavur city, Tamil Nadu, India," Environmental Monitoring and Assessment, vol. 171, no. 1-4, pp. 289-308, 2010.

[42] J. Ma, J. He, S. Qi et al., "Groundwater recharge and evolution in the Dunhuang Basin, northwestern China," Applied Geochemistry, vol. 28, pp. 19-31, 2013.

[43] H. Schoeller, "Qualitative evaluation of groundwater resources," in Methods and Techniques of Groundwater Investigations and Development, pp. 53-83, UNESCO, Paris, France, 1965.

[44] M. Kumar, K. Kumari, A. L. Ramanathan, and R. Saxena, "A comparative evaluation of groundwater suitability for irrigation and drinking purposes in two intensively cultivated districts of Punjab, India," Environmental Geology, vol. 53, no. 3, pp. 553574, 2007.

[45] P. Ravikumar and R. K. Somashekar, "A geochemical assessment of coastal groundwater quality in the Varahi river basin, Udupi District, Karnataka State, India," Arabian Journal of Geosciences, vol. 6, no. 6, pp. 1855-1870, 2013.

[46] S. Y. Chung, S. Venkatramanan, T. H. Kim, D. S. Kim, and T. Ramkumar, "Influence of hydrogeochemical processes and assessment of suitability for groundwater uses in Busan City, Korea," Environment, Development and Sustainability, vol. 17, no. 3, pp. 423-441, 2015.

[47] S. Sonkamble, A. Sahya, N. C. Mondal, and P. Harikumar, "Appraisal and evolution of hydrochemical processes from proximity basalt and granite areas of Deccan Volcanic Province (DVP) in India," Journal of Hydrology, vol. 438-439, pp. 181-193, 2012.

[48] T. E. Cerling, B. L. Pederson, and K. L. von Damm, "Sodiumcalcium ion exchange in the weathering of shales: implications for global weathering budgets," Geology, vol. 17, no. 6, pp. 552$554,1989$.

[49] R. J. Gibbs, "Mechanisms controlling world water chemistry," Science, vol. 170, no. 3962, pp. 1088-1090, 1970.

[50] Y.-L. Yu, X.-F. Song, Y.-H. Zhang, F.-D. Zheng, J. Liang, and L.C. Liu, "Identifying spatio-temporal variation and controlling factors of chemistry in groundwater and river water recharged by reclaimed water at Huai River, North China," Stochastic Environmental Research and Risk Assessment, vol. 28, no. 5, pp. 1135-1145, 2014.

[51] P. Ravikumar, R. K. Somashekar, and M. Angami, "Hydrochemistry and evaluation of groundwater suitability for irrigation and drinking purposes in the Markandeya River basin, Belgaum
District, Karnataka State, India," Environmental Monitoring and Assessment, vol. 173, no. 1-4, pp. 459-487, 2011.

[52] T. Y. Stigter, S. P. J. van Ooijen, V. E. A. Post, C. A. J. Appelo, and A. M. M. Carvalho Dill, "A hydrogeological and hydrochemical explanation of the groundwater composition under irrigated land in a Mediterranean environment, Algarve, Portugal," Journal of Hydrology, vol. 208, no. 3-4, pp. 262-279, 1998.

[53] J. Herrero and O. Pérez-Coveta, "Soil salinity changes over 24 years in a Mediterranean irrigated district," Geoderma, vol. 125, no. 3-4, pp. 287-308, 2005.

[54] M. Jalali, "Salinization of groundwater in arid and semi-arid zones: an example from Tajarak, western Iran," Environmental Geology, vol. 52, no. 6, pp. 1133-1149, 2007.

[55] M. N. Tijani, "Hydrogeochemical assessment of groundwater in Moro area, Kwara state, Nigeria," Environmental Geology, vol. 24, no. 3, pp. 194-202, 1994.

[56] V. D. Litskas, V. G. Aschonitis, E. H. Lekakis, and V. Z. Antonopoulos, "Effects of land use and irrigation practices on $\mathrm{Ca}, \mathrm{Mg}, \mathrm{K}$, Na loads in rice-based agricultural systems," Agricultural Water Management, vol. 132, pp. 30-36, 2014.

[57] G. Sposito and S. V. Mattigod, "On the chemical foundation of the sodium adsorption ratio," Soil Science Society of America Journal, vol. 41, no. 2, pp. 323-329, 1977.

[58] E. M. M. Wanda, L. C. Gulula, and A. Phiri, "Hydrochemical assessment of groundwater used for irrigation in Rumphi and Karonga districts, Northern Malawi," Physics and Chemistry of the Earth, vol. 66, pp. 51-59, 2013.

[59] A. Saleh, F. Al-Ruwaih, and M. Shehata, "Hydrogeochemical processes operating within the main aquifers of Kuwait," Journal of Arid Environments, vol. 42, no. 3, pp. 195-209, 1999.

[60] D. M. Joshi, A. Kumar, and N. Agrawal, "Assessment of the irrigation water quality of river Ganga in Haridwar district," Rasayan Journal of Chemistry, vol. 2, no. 2, pp. 285-292, 2009.

[61] F. M. Eaton, "Significance in carbonate in irrigation water," Soil Science, vol. 69, pp. 123-134, 1950.

[62] H. L. Bohn, B. L. McNeal, and G. A. O'Connor, Soil Chemistry, Wiley-Interscience, New York, NY, USA, 1985.

[63] N. Subba Rao, P. Surya Rao, G. Venktram Reddy, M. Nagamani, G. Vidyasagar, and N. L. V. V. Satyanarayana, "Chemical characteristics of groundwater and assessment of groundwater quality in Varaha River Basin, Visakhapatnam District, Andhra Pradesh, India," Environmental Monitoring and Assessment, vol. 184, no. 8, pp. 5189-5214, 2012.

[64] C.-S. Jang, S.-K. Chen, and Y.-M. Kuo, "Establishing an irrigation management plan of sustainable groundwater based on spatial variability of water quality and quantity," Journal of Hydrology, vol. 414-415, pp. 201-210, 2012.

[65] J. W. Lloyd and J. A. Heathcote, Natural Inorganic Hydrochemistry in Relation to Groundwater: An Introduction, Clarendon Press, Oxford, UK, 1985.

[66] I. Szaboles and C. Darab, "The influence of irrigation water of high sodium carbonate content of soils," in Proceedings of the 8th International Congress of ISSS, vol. 2, pp. 803-812, 1964.

[67] X.-C. Wang and P.-K. Jin, "Water quality issues related to water reuse for industries," Industrial Water \& Wastewater, vol. 43, pp. 1-5, 2012, (Chinese).

[68] P.-X. Fang, Z.-D. Wei, and Z.-S. Liao, Applied Hydrogeology, Geological Publishing House, Beijing, China, 1996, (Chinese).

[69] J.-F. Cao, B.-M. Chi, W.-K. Wang, H.-L. Gong, Y.-Q. Cao, and X.-J. Liang, Applied Hydrogeology, Science Press, Beijing, China, 2006, (Chinese). 

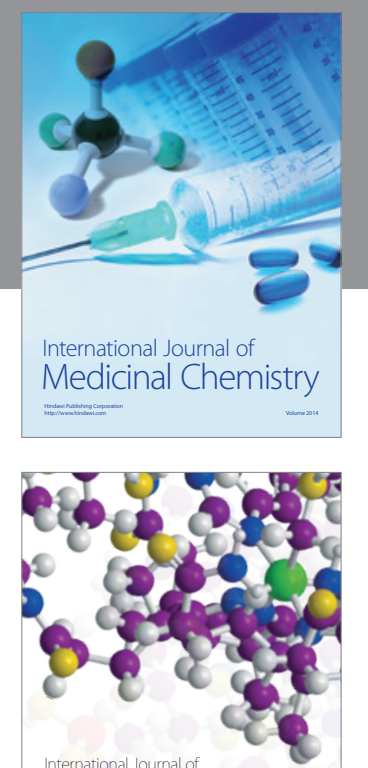

\section{Carbohydrate} Chemistry

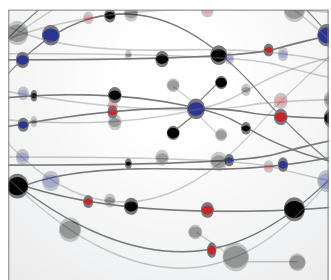

The Scientific World Journal
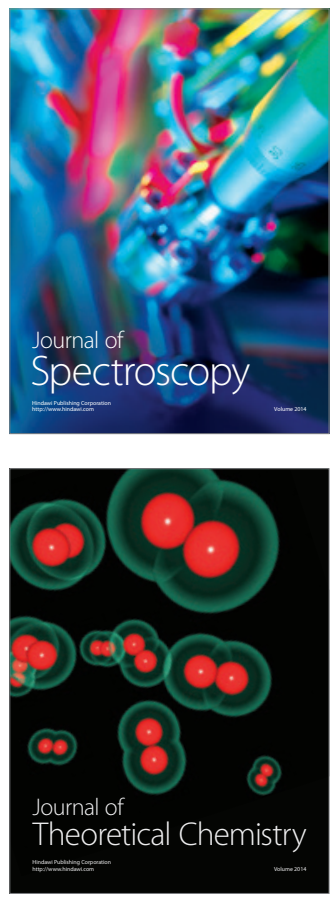
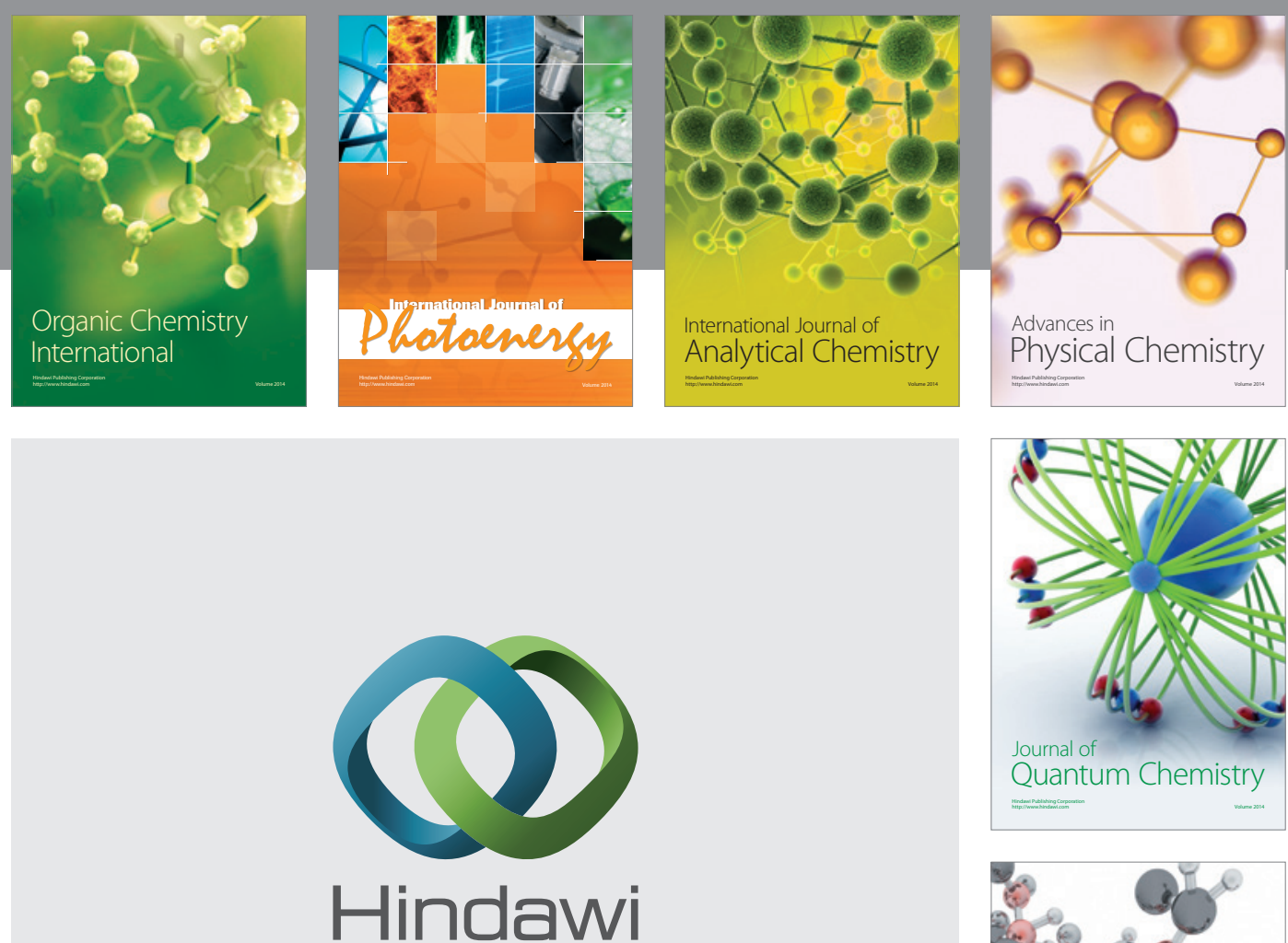

Submit your manuscripts at

http://www.hindawi.com

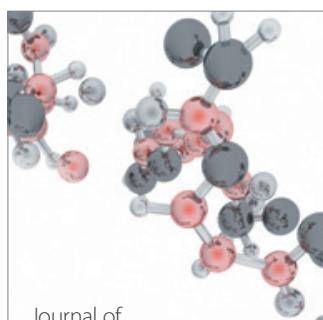

Analytical Methods

in Chemistry

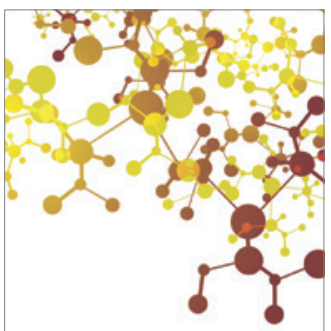

Journal of

Applied Chemistry

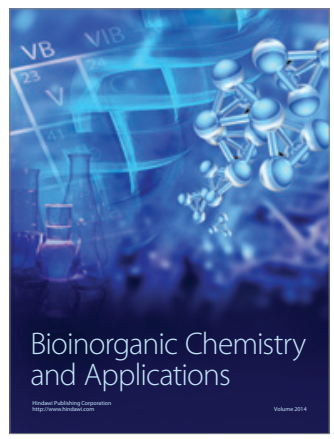

Inorganic Chemistry
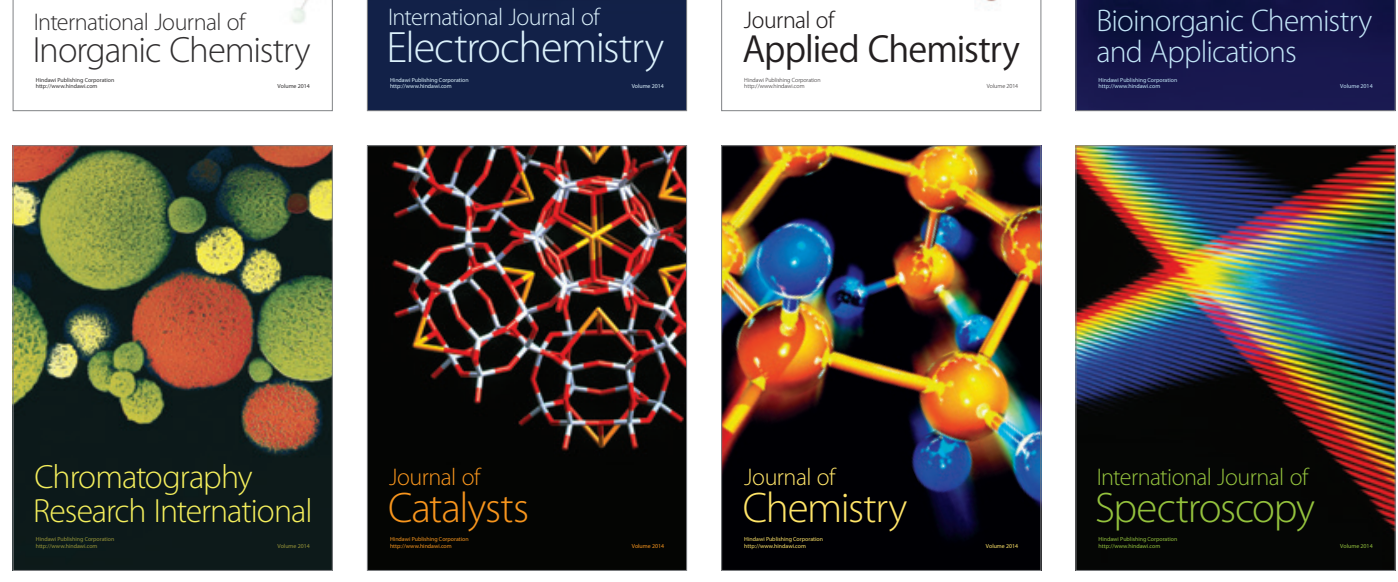